\title{
Beyond isolation: understanding past human-population variability in the Dutch town of Oldenzaal through the origin of its inhabitants and its infrastructural connections
}

\author{
L. M. Kootker ${ }^{1,2}$ - R. J. van Lanen ${ }^{3,4}$ - B. J. Groenewoudt ${ }^{3}$ - E. Altena ${ }^{5}$.



Received: 30 May 2017 / Accepted: 8 November 2017 / Published online: 27 November 2017

(C) The Author(s) 2017. This article is an open access publication

\begin{abstract}
This study presents a first attempt to assess the mechanisms and potential controls behind past residential mobility through the integration of isotopic data from human inhumations and spatial infrastructural information pertaining to the settlement containing these inhumations. Strontium $\left({ }^{87} \mathrm{Sr} /{ }^{86} \mathrm{Sr}\right)$ and oxygen $\left(\delta^{18} \mathrm{O}_{\mathrm{PDB}}\right)$ isotope data are derived from 200 (post)medieval individuals from the town of Oldenzaal in the present-day Netherlands. Reconstructions of historical route networks show that Oldenzaal was wellconnected interregionally throughout the Middle Ages and early-modern times (ca. AD 800-1600). Although the
\end{abstract}

L. M. Kootker and R. J. van Lanen contributed equally to this work.

Electronic supplementary material The online version of this article (https://doi.org/10.1007/s12520-017-0565-7) contains supplementary material, which is available to authorized users.

\section{M. Kootker}

lisette.kootker@vu.nl

1 Geology \& Geochemistry Cluster, Vrije Universiteit Amsterdam, De Boelelaan 1085, 1081 HV Amsterdam, the Netherlands

2 CLUE+ Research Institute for Culture, History and Heritage, Vrije Universiteit Amsterdam, De Boelelaan 1105, 1081

HV Amsterdam, the Netherlands

3 Cultural Heritage Agency, Smallepad 5, 3811 MG Amersfoort, the Netherlands

4 Faculty of Geosciences, Utrecht University, Heidelberglaan 2, 3584 CS Utrecht, the Netherlands

5 Department of Human Genetics, Leiden University Medical Centre, Einthovenweg 20, 2333 ZC Leiden, the Netherlands

6 ANTHRO.nl, Johan van Oldenbarneveltlaan 33, 3818 HA Amersfoort, the Netherlands

7 ACASA - Department of Archaeology, University of Amsterdam, Turfdraagsterpad 9, 1012 XT Amsterdam, the Netherlands working hypothesis was that in the past a high degree of spatial connectivity of settlements must have been positively related to a highly variable geographical origin of its inhabitants, the isotopic data from Oldenzaal indicate a population characterized by a low variability in terms of their origin. This unexpected result may be caused by (a combination of) various factors, related to (1) biases in the isotopic dataset, (2) interpretative limitations regarding the results of isotopic analyses and (3) the impact of broader socio-cultural factors that cannot be traced through isotopic analyses, such as infrastructural connectivity, socio-economics and political factors. The human oxygen isotope dataset presented here provides a first step towards a $\delta^{18} \mathrm{O}_{\mathrm{PDB}}$ reference dataset, against which future samples can be compared without the need to convert the data. This paper establishes that although in archaeology a biomolecular approach potentially provides a detailed reconstruction of the development of past populations in terms of palaeodemography and geographical/cultural origin, such studies should be performed in a transdisciplinary context in order to increase the understanding of the wider controlling factors of past population change.

Keywords Archaeology · Palaeomobility · Route networks · Strontium and oxygen isotopes · The Netherlands · Urban demography

\section{Introduction}

Since the initial application of stable and radiogenic isotope systems in archaeological research, population dynamics has emerged as an important research topic. Studies by Kreuger and Ericson during the mid-1980s have been recognised as ground-breaking work in palaeomobility research (Erickson 1985; Krueger 1985), and substantial progress has been 
realised since that time. Also due to its increasing popularity in archaeological studies (e.g. Cassidy et al. 2016; Morozova et al. 2016), new and detailed multidisciplinary investigations of prehistoric and historic population dynamics at a previously unobtainable resolution have become possible based on (1) significant developments in ancient genomics, (2) the application of multiple isotopic systems such as $\mathrm{Sr}-\mathrm{Pb}-\mathrm{H}-\mathrm{O}$ and (3) the generation of isoscape maps (e.g. Bataille et al. 2012; Bowen 2010; Evans et al. 2010; Kootker et al. 2016b; Willmes et al. 2014). To date, however, studies combining significant amounts of human DNA and isotopic data with the aim to infer information about the spatial and temporal variations in ancient population compositions (i.e. demography and geographical origins) are rare, despite successful applications throughout the last decade (e.g. Haak et al. 2008; Naumann et al. 2014; Prowse et al. 2010).

Although a biomolecular approach potentially provides data suitable for a detailed reconstruction of the development of ancient populations, it is vital to understand the wider controlling factors of population change. Key questions are (1) what were the driving forces behind population growth and decline, (2) what were the physical options for translocation in the research area and (3) what were societal possibilities and challenges for 'immigrants' in this area? The successful reconstruction of residential mobility and population development in the past using biomolecular methods in part depends on factors wholly unrelated to mobility patterns, such as excavation strategy, state of conservation (i.e. geochemical environment), sampling process and studied number of individuals. When dealing with standard archaeological contexts such as general cemeteries, the influence of these factors may well lead to nonrepresentative estimations of the extent of residential mobility. However, the socio-economic potential and development of a settlement can be determined independently, based on its degree of linkage to well-connected and frequently used communication and transport networks. The expectation is that settlements which in the past were well-connected infrastructurally also provided receptive environments for immigrants.

To date, most palaeomobility studies have focused on the identification of non-local individuals, rather than on interpreting the data in a wider context by also considering the level of connectivity and the socio-economic development and growth of settlements. This paper presents a first attempt to assess the mechanisms and potential controls behind past mobility, using a (post)medieval population from the main cemetery associated with the current St. Plechelm church in the centre of the present-day city of Oldenzaal, the Netherlands. Bioarchaeological investigations were carried out on 200 individuals, focusing on retrieving osteoarchaeological, DNA and $\mathrm{Sr}-\mathrm{O}-\mathrm{C}-\mathrm{N}$ isotope data. This has resulted in one of the largest bioarchaeological datasets of this type presently assembled from a single population in Europe (Altena et al. 2016; Williams 2016). Bioarchaeologically, the present study focuses on coupled strontium and oxygen isotope analyses of dental enamel samples from this population. The theoretical extent of mobility, which is partly determined by the physical landscape, is modelled through the integration of biological sex, isotopic data and a literature-based reconstruction of the degree in which Oldenzaal was infrastructurally connected to other settlements locally, regionally and interregionally. Past routes represent frequent-travel zones as well as areas characterised by relatively high levels of human activity, since they provided communication channels as well as arteries of trade and transport (Van Lanen et al. 2016; Van Lanen and Pierik 2017). Therefore, one might expect a positive correlation between settlement connectivity on the one hand and population variability and dynamics on the other hand. The aim of this study is therefore to explore whether the degree in which Oldenzaal was connected to the outside world also is expressed by the quantitative degree of variability in terms of the geographical origin of its former population.

\section{Research area}

\section{Geographical setting}

Oldenzaal is situated in the Twente area in the eastern Netherlands. Geologically, the area is part of the northwestEuropean sand belt (Koster 2009; Tolksdorf and Kaiser 2012, Fig. 1). The major geological features were formed as a result of the combined activity of wind, water and ice during the Saalian and Weichselian Ice Ages (Van Beek, 2009). The expansion of land ice in the Saalian led to the formation of glacial moraines that consist of pushed-up sand, boulder clay and (some) marine clay. The city of Oldenzaal is situated on the slope of one of these ridges. The areas between the glacial moraines are relatively flat. Raised bogs developed in these poorly drained lands from the late Atlantic and Subboreal periods onwards (Van Beek et al. 2015b). Until the Late Middle Ages, raised bogs and other types of wetland were scattered throughout the landscape (De Rooi 2008; Van Beek, 2009). Since prehistoric times the higher parts of Twente have been relatively densely populated (Van Beek, 2009). Twente was first mentioned in eighth-ninth-century historical documents as a shire (Heidinga 1987a,b). By then, settlement pressure had already caused substantial deforestation; a process that resulted in the development of relatively open landscapes (Groenewoudt et al. 2007; Van Beek et al. 2015a). Due to on-going desiccation, and the expansion of raised bogs, Twente gradually became an inhabited 'island', largely surrounded by virtually uninhabited and poorly accessible wetlands. This especially holds true for its northern and western borders, but to a lesser degree also for those in the east and south. Large-scale drainage and reclamation of wetlands only gained pace from the late sixteenth century onwards (Gerding 1995). 
Fig. 1 Above - the European aeolian sand belt (after (Hilgers 2007)). The black arrow points at the location of Oldenzaal.

Below - the location of the Twente region and Oldenzaal in the Netherlands


\section{Oldenzaal and St. Plechelm's cemetery}

Oldenzaal's history can be traced back to the Early Middle Ages (AD 450-1050), with the oldest archaeological evidence (radiocarbon data of inhumed individuals) dating back to the $\mathrm{AD}$ seventh-eighth centuries (Oude Nijhuis 2007; Weustink 1962; Williams 2016). The first written evidence for the existence of Oldenzaal is found in a late ninth-century register of the properties belonging to the Benedictine Prüm Abbey in Germany (the Prümer Urbar). By the end of the tenth century, the medieval diocese of Utrecht had founded a chapter in Oldenzaal, had restored and expanded an old wooden church, and had rededicated this church to Saint Plechelm (Van Vliet 2002).

In AD 1049, Emperor Hendry III authorised Oldenzaal to hold weekly markets and annual fairs (Utrecht archive: fo 14v). These markets were essential for the economic development and the commercial growth of Oldenzaal (Rutte and van Engen 2007). In AD 1261, 12 years after Oldenzaal had been granted borough rights (which are town privileges, such as trade and the establishment of guilds), the town signed a trade 
agreement with the German Hanseatic league member Coesfeld. With this agreement, Oldenzaal became a member of the Hanseatic League, an economic alliance of key trading cities that held a trade monopoly along the coast of Northern Europe during the thirteenth to seventeenth centuries (Beerbühl Schhulte 2013). Although land routes were of importance during the early days of the League, most long-distance bulk transport took place via waterways. As a result, most Hanseatic towns were situated close to, or directly bordering on, water routes. Oldenzaal did not conform to this criterion, but its convenient geographical situation close to the German border potentially made it a suitable gateway city for the funnelled transit traffic between the Holland provinces, regional Hanseatic members such as Deventer, Zutphen, Zwolle, and the eastern hinterland.

During the Hanseatic League's heydays (circa AD 13701475), over 200 towns in northern Europe, from the North Sea to Baltic Sea, were connected (Beerbühl Schhulte 2013). Successful linkage between water and land routes can be considered as one of the responsible factors for the prolonged existence of the League (Brand 2007; Seyger 2005). The demise of the League was largely caused by the rise of the Atlantic trading system, which was most beneficiary for Antwerp, Amsterdam and London. Eventually, the former Hanseatic trading business slowly transferred to Dutch hands (notably the provinces of Holland and Zeeland), and the termination of the League became final in AD 1669 (Brand 2007; Dollinger 1998).

St. Plechelm Church was the main church of the archdeaconate of Twente from the eleventh century onwards (Van Vliet 2002). Historical documents pertaining to Oldenzaal mention circa 1000 inhabitants in AD 1400 and an increase of the population up to circa 1600 inhabitants in $\mathrm{AD}$ 1670 (Lourens and Lucassen 1997). The cemetery of St. Plechelm has been used for the interment of the deceased from Oldenzaal and its surrounding 'commons' (farmers' communities) for at least 1000 years, with the possible first burial dating to the period between AD 616 and 809 (Williams 2016). Based on seventeenth-century written documents, each common was responsible for the maintenance of a specific part of the cemetery wall (Goorhuis 2009). This may point at a deliberate spatial organisation of deceased from particular commons within the cemetery, but historical evidence for this hypothesis is lacking.

\section{Material and methods}

\section{Sample selection}

During archaeological excavation campaigns in 2011-2013, skeletal remains of 2750 primary burials were unearthed within an area of about $5000 \mathrm{~m}^{2}$ (Fig. 2). Over a thousand primary burials were sampled (37\% of the excavated population, Williams 2016). The final selection of 200 individuals for bioarchaeological investigations was based on (1) the completeness of the skeleton, which is important to accurately establish the sex and age of the individuals; (2) the presence of dental elements for DNA and isotopic analysis and (3) the ability to date the individuals using radiocarbon dating and the analysis of archaeological sequence diagrams (i.e. Harris matrices-Harris 1975, ArchEd Version 1.4.1, TU Wien). Concerning chronological age, two main periods were selected based on the need to date as many skeletons as possible and on the potential to compare resulting demographic data with contemporaneous populations in the Netherlands. These periods respectively are $\mathrm{AD} \sim 600-1500$ and $\mathrm{AD} 1500-1829$ (cf. Williams 2016).

The individuals were selected from five locations at the north side, and the north(west) and south(west) edges of the cemetery (labelled A to E; Fig. 2), where (1) depth and sequence of burial provided a sufficient time range spanning most of the period of use of the cemetery and (2) intersections of burials allowed for optimal dating possibilities. Although these individuals represent a period of more than 1000 years, the selection can be considered extensive given the relatively low number of inhabitants of Oldenzaal (see Oldenzaal and St. Plechelm's cemetery).

During the excavations, three dental elements per individual were sampled simultaneously for DNA and isotopic analysis under contamination-controlled (forensic) conditions by qualified physical anthropologists and archaeologists. These samples immediately were stored in freezers at $-20^{\circ} \mathrm{C}$. Based on presence and severity of dental caries, root completeness and other factors, the two best-preserved elements were selected for DNA analysis, with the remaining sample being made available for isotopic analysis. If the state of preservation of the three elements was comparable, the first permanent molar was preferred for isotopic analysis. Enamel of first permanent molar mineralises within the first 3 years after birth and therefore captures the isotopic signature of their earliest childhood residency (Nelson and Ash 2010). The selection of the first permanent molar is in accordance with the initial research design which was specifically focussed on the identification of non-locally born individuals. However, we note that this approach may have caused complications in respect of the interpretation of the oxygen isotope data due to the isotopic fractionation associated with breastfeeding (see Delineation of local strontium and oxygen isotope ranges).

\section{Determination of age at death and biological sex}

In order to compare mobility patterns between men and women, the sex of the studied individuals was determined by a combination of physical anthropological methods and DNA analysis, with the results of the latter being given preference. The first approach consisted of inspecting the pelvis and skull for the presence of morphological features known to be 
Fig. 2 Overview of the excavated primary burials $\left(5000 \mathrm{~m}^{2}\right)$, the spatial distribution of 2750 primary burials and the location of the five zones (A-E) from which 200 individuals were selected for bioarchaeological analysis (@) ADC

ArcheoProjecten)

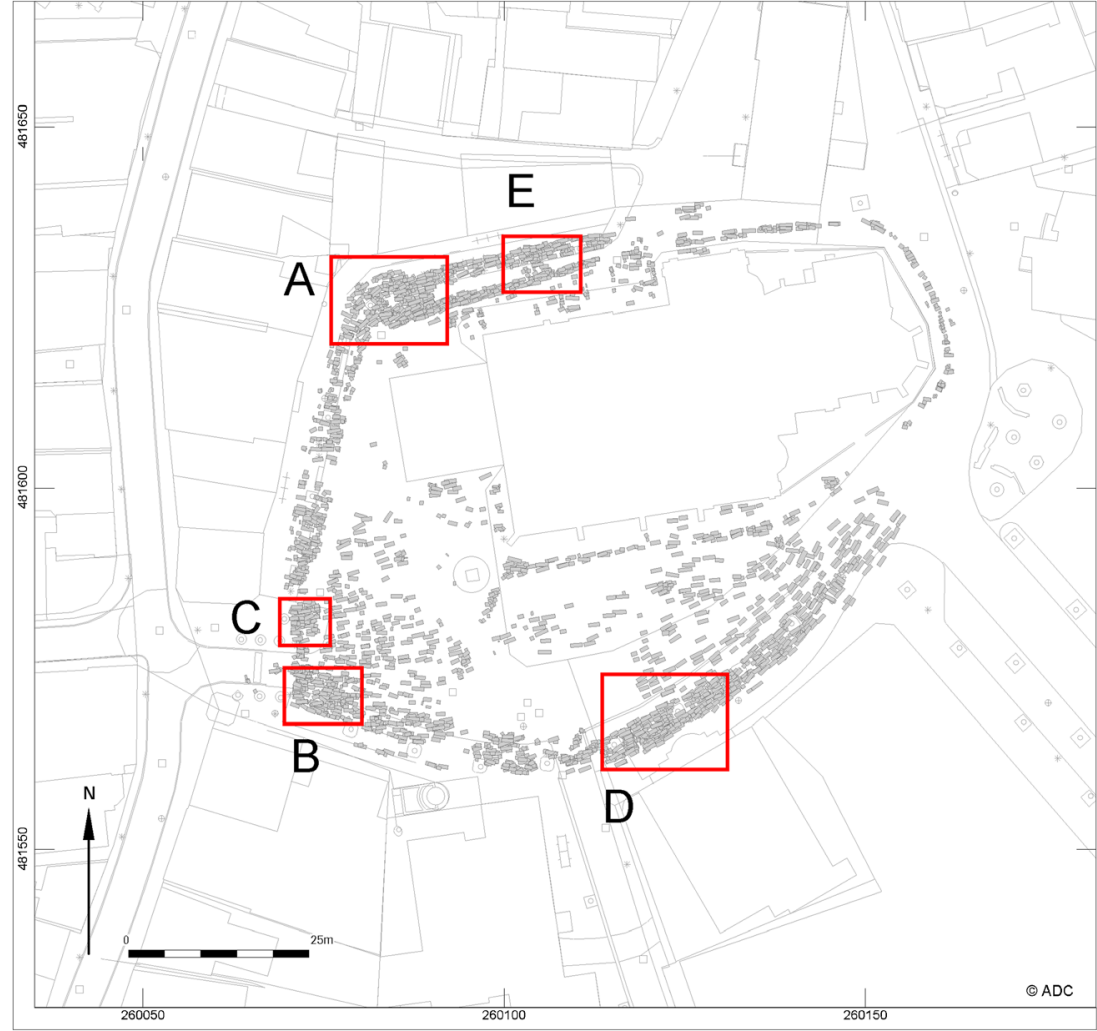

associated with sexual dimorphism. These features were scored following the criteria recommended by the Workshop of European Anthropologists (Workshop of European Anthropologists 1980). Since this approach is unreliable when dealing with individuals younger than circa 15 years, this age group was excluded from this stage of the analysis. For individuals with an estimated age at death of 15-20 years, the results were accepted only if sufficient features could be inspected (50\% or more of the weighed features) and if a clear result was obtained (i.e. a sexualisation degree outside the range of -0.50 to +0.50 ). Age at death in young individuals was estimated by inspection of the development and eruption of the dentition (Moorrees et al. 1963; Ubelaker 1989; Workshop of European Anthropologists 1980), growth of the long bones (Maat et al. 2002; Maresh 1955) and union of the epiphyses (Schaefer et al. 2009).

All DNA work was carried out at the department of Human Genetics of the Leiden University Medical Center. A strict quality control is of great importance in conducting ancient DNA analysis because of potential problems with degradation and contamination. Therefore, all actions prior to DNA amplification were performed in a laboratory space specifically equipped for ancient DNA analysis. Extensive measures were taken during the laboratory work and the analysis and interpretation of the results obtained to avoid and track contamination.

For sample preparation and DNA isolation, see supplementary information. To determine biological sex, the presence or absence of the male-specific Y chromosome was investigated. To determine whether or not a Y chromosome was present, the presence of the Y chromosome-specific SRY gene was tested with the Quantifiler® Duo kit (Applied Biosystems) and the amelogenin gene was typed with both the PowerPlex ${ }^{\circledR}$ ESX 16 and PowerPlex ${ }^{\circledR}$ ESI 16 systems (Promega, see supplementary information for detailed information). The amelogenin gene is located on both the $\mathrm{X}$ and the $\mathrm{Y}$ chromosome, but the gene on the $\mathrm{Y}$ chromosome is longer than on the $\mathrm{X}$ chromosome.

An individual was regarded as male when indications were observed for the presence of a Y chromosome with the Quantifiler® Duo kit and/or the PowerPlex® ESX 16 and PowerPlex® ESI 16 systems. The absence of a Y chromosome could either point towards a female individual or the possibility that the DNA from the Y chromosome was too degraded to be observed. If for less than five markers alleles were obtained with each PowerPlex® ESX 16 and PowerPlex® ESI 16 PCR, and any indication for the presence of the Y chromosome remained absent, a biological sex was not determined, due to possible degradation issues. An individual was regarded as female when there were no indications for the presence of a Y chromosome, and at least for one PCR with the PowerPlex ${ }^{\circledR}$ ESX 16 and PowerPlex ${ }^{\circledR}$ ESI 16 systems alleles could be obtained for at least five markers. It is possible, however, that in case of a deletion on the male amelogenin gene, it can be mistaken for the shorter female 
variant. The prevalence of such a deletion, however, is extremely low in European men $(0-0.018 \%$, Santos et al. 1998; Steinlechner et al. 2002).

\section{Strontium and oxygen isotope analysis}

The dental elements were cleaned with demineralised water and dried at room temperature for $24 \mathrm{~h}$. Approximately 2$3 \mathrm{mg}$ and $1 \mathrm{mg}$ of enamel powder were sampled for strontium and oxygen isotope analysis, respectively, using a small acidcleaned diamond ball bur. The strontium isotope samples were sealed in hydrochloric acid pre-cleaned $2 \mathrm{ml}$ polyethylene Eppendorf® centrifuge tubes and transferred to a US Federal Standard Class 100 clean laboratory facility at the Vrije Universiteit Amsterdam for $\mathrm{Sr}$ purification. The oxygen isotope samples were collected in small glass vials and transferred to the stable isotope laboratory.

Strontium column extraction and sample loading were performed following the protocols described in (Kootker et al. 2016a). The isotope compositions were measured by thermal ionisation mass spectrometry using a Finnigan MAT-262 RPQ-plus and a Thermo Scientific ${ }^{\mathrm{TM}}$ Triton Plus $^{\mathrm{TM}}$ instrument. The strontium ratios were determined using a static routine and were corrected for mass fractionation to ${ }^{86} \mathrm{Sr} /{ }^{88} \mathrm{Sr}$ ratio of 0.1194 . All measurements were referenced to the within-run value of the NBS987 standard. Measurements of NBS987 gave an average ${ }^{87} \mathrm{Sr} /{ }^{86} \mathrm{Sr}$ ratio of $0.710241 \pm 0.000009$ (2SE, $n=16)$ and $0.710255 \pm 0.000009$ (2SE, $n=12$ ) for the MAT-262 and the Triton, respectively. The total procedural blanks $(n=14)$ contained a negligible amount of $\mathrm{Sr}$ (on average $39 \mathrm{pg}$ ).

Prior to the oxygen isotope analysis, the enamel powder samples were pre-leached in $1 \mathrm{ml} 2.5 \%$ sodium hypochlorite solution $(\mathrm{NaClO})$ to remove organic matter. After 24-h, the samples were centrifuged and the supernatant removed. The samples were than washed four times with Milli-Q water to ensure complete removal of the $\mathrm{NaClO}$ solution. A $0.1-\mathrm{M}$ acetic acid $\left(\mathrm{CH}_{3} \mathrm{COOH}\right)$ was then added for 24-h to remove secondary carbonates, which are also potentially introduced by the $\mathrm{NaClO}$ pre-treatment step (see e.g. Snoeck and Pellegrini 2015; Pellegrini and Snoeck 2016). Pre-treatment steps to remove organics and/or carbonates of bioapatite samples are often applied to enamel samples in archaeological research, but the best approach is a matter of debate. The different protocols reported in the literature appear to have an influence the biogenetic $\delta^{18} \mathrm{O}$ signal retained in enamel (Pellegrini and Snoeck 2016). Based on experiments reported by Pellegrini and Snoeck (2016), a slight isotopic enrichment $(<0.5 \%$ o of our archaeological enamel samples may be expected.

Subsamples of approximately $0.3 \mathrm{mg}$ of enamel powder were taken and were placed in exetainer vials and flushed with pure helium (5.0). Phosphoric acid $\left(\mathrm{H}_{3} \mathrm{PO}_{4}\right)$ was added for $24 \mathrm{~h}$ at a constant temperature of $45{ }^{\circ} \mathrm{C}$ to dissolve the samples. The isotope composition was analysed using a Thermo Finnigan GasBench II preparation device interfaced with a Thermo Finnigan Delta+ mass spectrometer. The measured isotope values were normalised to the Vienna Peedee Belemnite (VPDB) scale using an in-house carbonate reference material (VICS) calibrated against NBS19 and LSVEC certified reference materials. The international control standard IAEA-CO1 was used to check instrument performance (average -2.16 , $n=3$ ). The reproducibility of IAEA-CO1 during the analytical session was $\pm 0.12 \%$ o $(1 \sigma)$. To compare the data with available 'local' oxygen isotope datasets to help define a local oxygen isotope signature (see Delineation of local strontium and oxygen isotope ranges), data for structural carbonate $\delta^{18} \mathrm{O}$ were recalculated relative to Vienna Standard Mean Ocean Water (VSMOW) and drinking water (DW) using eqs. 1 and 2, respectively (Chenery et al. 2012; Coplen 1988):

$$
\begin{aligned}
& \delta^{18} \mathrm{O}_{V S M O W}=1.03091 \times \delta^{18} \mathrm{O}_{\mathrm{PDB}}+30.91 \\
& \delta^{18} \mathrm{O}_{\mathrm{DW}}=1.590 \times \delta^{18} \mathrm{O}_{\text {VSMOW }}-48.634
\end{aligned}
$$

The use of these conversion equations, however, undoubtedly introduced errors. Research conducted by Pollard et al. (2011) and Chenery et al. (2012) show that the error associated with conversion equations can be as high as 1 to circa $3.5 \%$. Although both studies refer to the regressions of phosphate oxygen versus drinking water, the same principles also apply to the carbonate oxygen. The obtained converted data therefore will be used as a guide rather than accepted as accurate values (cf. Chenery et al. 2012, p. 315).

\section{Delineation of local strontium and oxygen isotope ranges}

In order to produce an accurate interpretation of the generated isotopic data, local strontium and oxygen isotope values must be defined. Kootker et al. (2016b) suggested a multidisciplinary approach to delineate a local strontium isotope range, combining a local isotope map with appropriate (modern) biosphere samples and a statistical assessment of the investigated population. Hence, to enable a careful assessment of the local ${ }^{87} \mathrm{Sr} /{ }^{86} \mathrm{Sr}$ ratios, in this study, the Dutch archaeological bioavailable strontium isoscape map (Kootker et al. 2016b) was combined with a statistical assessment of the Oldenzaal population (see Statistical assessments).

The definition of a local oxygen isotope baseline is a more complex procedure. Large intra- and intersite variations in human $\delta^{18} \mathrm{O}$ values across Europe have been recognised. Recent studies show the existence of a high degree of overlap in (archaeological) human oxygen isotope values in Europe, and advocate not to use oxygen isotope analysis alone for provenancing purposes (e.g. Lightfoot and O'Connell 2016; Pellegrini et al. 2016). Therefore, an integrated approach has been adopted to achieve the best possible resolution in the delineation of local oxygen isotope signals. Ideally, to avoid the 
uncertainties associated with the available conversion equations (see above), human and (faunal) background $\delta^{18} \mathrm{O}_{\mathrm{PDB}}$ or $\delta^{18} \mathrm{O}_{\text {phosphate }}$ data are used to enable direct comparisons between the investigated population and the local regions against which the generated data can be compared (Pollard et al. 2011; Lightfoot and O'Connell 2016; Pellegrini et al. 2016). However, the development of (regional/national) datasets containing local (human and faunal) $\delta^{18} \mathrm{O}_{\mathrm{PDB}}$ data is still in its infancy (see Pellegrini et al. 2016 for a first geostatistical model of spatial variation in the distribution of unconverted human $\delta^{18} \mathrm{O}_{\text {phosphate }}$ data). Hence, one has to rely on the existing drinking water values to detect a relation between measured oxygen isotope values and geographic regions (Chenery et al. 2012). For this reason, the obtained human $\delta^{18} \mathrm{O}_{\mathrm{PDB}}$ values are converted to $\delta^{18} \mathrm{O}_{\mathrm{DW}}$ values to allow such a comparison between the obtained human and the environmental data. In this study, 'local' $\delta^{18} \mathrm{O}_{\mathrm{DW}}$ data from (1) the Global Network of Isotopes in Precipitation (GNIP: IAEA/WMO 2016), (2) modern tap water samples from the Netherlands (Font et al. 2015), (3) the schematic West-European $\delta^{18} \mathrm{O}_{\mathrm{DW}}$ isoscape map (Compiled by C. Chenery, based on Darling et al., 2003, and Lecolle 1985), (4) $\delta^{18} \mathrm{O}_{\mathrm{PDB}}$ data of modern individuals from the Netherlands who had not spent more than 30 days outside the Netherlands between the age of 7 and 16 (Font et al. 2015) and (5) a statistical assessment of the Oldenzaal $\delta^{18} \mathrm{O}_{\mathrm{PDB}}$ data (see Statistical assessments) were combined to define the local oxygen isotope signal.

Due to the fact that the human dataset includes primarily $\delta^{18} \mathrm{O}_{\mathrm{PDB}}$ data of first permanent molars, a possible positive isotopic shift due to the 'breastfeeding-effect' should be taken into account as well. Several researchers have shown slight differences in $\delta^{18} \mathrm{O}$ between dental elements that mineralise before (e.g. deciduous dental elements and the first permanent molar) and after weaning due to the metabolic processes that take place during breastfeeding (e.g. McPherson 2005; Wright and Schwarcz 1998). First permanent molars may therefore be isotopically enriched by up to circa $1 \%$, dependent on the intensity and duration of breastfeeding during the mineralisation of the dental enamel (e.g. Wright and Schwarcz 1998). However, weaning ages in Medieval the Netherlands, and Oldenzaal in particular, have yet to be established. It is, therefore, difficult to accurately correct for this effect.

\section{Statistical assessments}

Several statistical tests were performed to gain additional information on the local bioavailable background strontium isotope ratios and to test whether established differences between groups are significant. For the determination of the local strontium isotope signature, the distribution of the dataset was assessed by a Shapiro-Wilk test at a $p=0.05$ level. Boxplots were generated to aid in the identification of mild and extreme outliers, i.e. values that deviate from a normal distribution. Based on the visual representation of the distribution of the strontium isotope data, outliers were removed from the dataset to allow the value of skewness of the distribution to approximate 0 (i.e. a symmetric distribution). This approach resulted in a trimmed and symmetrical, normally distributed 'local ${ }^{87} \mathrm{Sr} /{ }^{86} \mathrm{Sr}$ dataset (see Wright 2005). Non-parametric Mann-Whitney $U$ tests (Mann and Whitney 1947) were performed to test for statistically significant differences between groups. All statistical assessments were performed using SPSS 23.0 (IBM SPSS Statistics for Macintosh, Armonk, IBM Corp.).

\section{Spatial infrastructural information}

The oldest available overview of supraregional road networks in the Netherlands was made by Horsten (2005) for the period around $\mathrm{AD} 1600$. In this historical road atlas, the major interregional routes in the Netherlands were reconstructed for three periods: AD 1600, 1800 and 1848. For the purpose of this study, detailed reconstructions of pre-modern route networks of the Twente area were derived from recent studies by Van Lanen et al. (2015a, b; 2016). These authors reconstructed route networks active during the Roman, early-medieval and early-modern periods (ca. AD 100, 800 and 1600, respectively) based on the network-friction approach, which models the degree of local accessibility of an area based on landscape prerequisites for potential route networks, route-network modelling and old maps. To enable an accurate assessment of Oldenzaal's level of connectivity, additional information on Oldenzaal's geographical setting, historical infrastructure and city development was extracted from a variety of written sources ranging from historical studies, specialised academic papers, regional landscape-archaeological overview studies and archaeological excavation reports (for the sources used in the analysis, see Results and data interpretation).

\section{Results and data interpretation}

\section{Population diversity in terms of biological sex}

Inconsistencies between sample documents and database inputs lead to the exclusion of two female individuals (V1730 and V1858) from the Oldenzaal sample, since the dental elements could not be positively assigned to individual skeletal remains. This reduced the dataset to 198 individuals (see Table 5). Circa $41 \%$ of the individuals could be dated to $\mathrm{AD} \sim 600-1500$ ( $n=$ $81)$ and circa $44 \%$ to $\mathrm{AD} 1500-1829(n=87$, see Table 1$)$. The remaining 30 individuals (15\%) could not be accurately dated.

For 189 individuals, sex was determined by respectively DNA analysis (173 individuals) and physical anthropological methods (16 individuals), resulting in the identification of 98 females (52\%) and 91 males (48\%). The identified AD 6001500 population contains more females $(n=49)$ than males 
Table 1 Summary of the obtained ${ }^{87} \mathrm{Sr} /{ }^{86} \mathrm{Sr}$ and $\delta^{18} \mathrm{O}_{\mathrm{PDB}}$ data from Oldenzaal, the Netherlands $(n=\max 198)$

\begin{tabular}{clccccc}
\hline & Total & Male & Female & AD $<1500$ & AD $>1500$ \\
\hline${ }^{87} \mathrm{Sr}{ }^{86} \mathrm{Sr}$ & Count & 198 & 91 & 98 & 81 & 87 \\
& Mean & 0.71031 & 0.71030 & 0.71032 & 0.710261 & 0.71031 \\
& Median & 0.71029 & 0.71023 & 0.71033 & 0.710288 & 0.71028 \\
& Std. deviation & 0.00069 & 0.00079 & 0.00061 & 0.00064 & 0.00076 \\
& Minimum & 0.70843 & 0.70863 & 0.70843 & 0.70863 & 0.70843 \\
& Maximum & 0.71421 & 0.71421 & 0.71253 & 0.71253 & 0.71421 \\
$\delta^{18} \mathrm{O}_{\text {PDB }}$ & Count & 188 & 86 & 94 & 75 & 86 \\
& Mean & -5.12 & -5.13 & -5.12 & -5.00 & -5.23 \\
& Median & -5.02 & -5.05 & -5.10 & -4.93 & -5.24 \\
& Std. deviation & 0.51 & 0.53 & 0.52 & 0.48 & 0.53 \\
& Minimum & -7.26 & -7.26 & -6.24 & -6.24 & -7.26 \\
& Maximum & -3.80 & -4.04 & -3.80 & -3.80 & -4.22 \\
\hline
\end{tabular}

$(n=29)$, while the biological sex ratio is nearly neutral for the following period ( $n=40$ and $n=47$, respectively, see Table 5).

Strontium isotope analyses were successfully applied to all 198 individuals (Tables 1 and 5). The resulting ${ }^{87} \mathrm{Sr} /{ }^{86} \mathrm{Sr}$ ratios vary between 0.70843 and $0.71421\left(\Delta^{87} \mathrm{Sr} /{ }^{86} \mathrm{Sr}_{\max }\right.$ $\left.-{ }^{87} \mathrm{Sr} /{ }^{86} \mathrm{Sr}_{\min }=0.00577\right)$. The male dataset ranges from 0.70863 to 0.71421 , while the female dataset has less variation, with values between 0.70843 and 0.71253 . The medians of both datasets ( 0.71023 for males and 0.71033 for females) do not differ significantly at the $p=0.05$ level $(U=4138, z=$ $-0.853, p=0.394)$. Oxygen isotope analyses were successfully applied to 188 individuals. The observed $\delta^{18} \mathrm{O}_{\mathrm{PDB}}$ values vary between -7.3 and $-3.8 \%$ o. The male dataset $(n=86$, 7.3 to $-4.0 \%$ ) is again more dispersed than the female dataset ( $n=94,-6.2$ to $-3.8 \%$ ), but this difference is statistically insignificant ( $U=3924, z=-0.339, p=0.735)$. A further intergroup comparison was made for the AD 600-1500 and AD 1500-1829 periods. Non-parametric tests exhibited insignificant differences in the median of the two periods for both ${ }^{87} \mathrm{Sr} /{ }^{86} \mathrm{Sr}$ ratios and $\delta^{18} \mathrm{O}_{\mathrm{PDB}}$ values $(U=3475, z=-0.154$, $p=0.878$ and $U=3924, z=-0.206, p=0.837$, respectively). The absence of statistical significant differences between the sexes and the periods may translate to insignificant differences in the variety in geographical origins between males and females and between the pre- and post AD 1500 populations.

\section{Delineation of local strontium and oxygen isotope data}

Oldenzaal is located on the boundary of Sr isoscapes $\mathrm{C}$ and $\mathrm{E}$ (Fig. 3). Based on this map, a relative wide range of strontium isotope values varying between 0.7091 and 0.7110 is consistent with the local and even with the regional environment. A Shapiro-Wilk analysis, however, rejects the assumption that the ${ }^{87} \mathrm{Sr} /{ }^{86} \mathrm{Sr}$ data are normally distributed $(W=0.952, \mathrm{df}=$ $198, \alpha=0.000)$. Through the removal of outliers $(n=15)$, a trimmed, but nearly symmetrical mesokurtic (excess kurtosis approximates 0$)$ normally distributed dataset $(W=0.987, \mathrm{df}=$
183, $\alpha=0.104$ : trimmed dataset) is created with strontium isotope values ranging between 0.70910 and 0.71152 (Table 2, Fig. 4). The trimmed dataset is considered to be the best representation of the local population (Wright 2005). Although $75 \%$ of the population falls within the 0.7097 0.7110 range, a conservative route is taken to reduce the possible overestimation of non-local individuals. Hence, a range of $0.7091-0.7115$ is used to define the regional environment.

A statistical analysis of the $\delta^{18} \mathrm{O}_{\mathrm{PDB}}$ data shows a nearly symmetrical mesokurtic normally distributed dataset $(W=$ 0.988 , df $=187, \alpha=0.101$ ) ranging between -6.3 and $3.8 \%$ after removal of one mild outlier $(-7.3 \%$, V1694, Fig. 4). These $\delta^{18} \mathrm{O}_{\mathrm{PDB}}$ data correspond with $\delta^{18} \mathrm{O}_{\mathrm{DW}}$ values ranging between circa -10 and $-6 \%$. This $\delta^{18} \mathrm{O}_{\mathrm{DW}}$ range is, however, not adopted in our attempt to delineate the local signal due to the errors associated with the conversion equation. However, these data do show that 'the Netherlands' is likely to be characterised by a relative wide range of $\delta^{18} \mathrm{O}_{\mathrm{DW}}$ values. Following Chenery et al. (2012), these values are therefore interpreted as guide values, rather than an accurate representation of the 'Dutch' $\delta^{18} \mathrm{O}_{\mathrm{DW}}$ values.

An overview of all available background $\delta^{18} \mathrm{O}$ data is given in Table 3. The GNIP shows a wide range of $\delta^{18} \mathrm{O}_{\text {VsMow }}$ values $(-9.2$ to $-5.1 \%$ ). These modulations, however, are not as accurate as local water analyses and therefore may not


2008; Hamre and Daux 2016). Nevertheless, the GNIP data does overlap significantly with $\delta^{18} \mathrm{O}_{\text {VsMow }}$ values of modern Dutch tap water samples $(-7.0 \pm 1.1 \%$ ) and with the assumed local range based on the schematic West-European $\delta^{18} \mathrm{O}_{\mathrm{DW}}$ isoscape map ( \pm-7.5 to $6.0 \%$ ). It must be taken into account, however, that the schematic West-European $\delta^{18} \mathrm{O}_{\mathrm{DW}}$ isoscape map is based on a limited number of samples, of which most were taken from the UK (Darling et al. 2003), which compromises its accuracy and reliability for continental Europe. Moreover, tap water values may not accurately represent local human oxygen isotope values, as human $\delta^{18} \mathrm{O}$ values 
Fig. 3 Detailed section of the Oldenzaal region in the ${ }^{87} \mathrm{Sr} /{ }^{86} \mathrm{Sr}$ isoscape map of the Netherlands (Kootker et al. 2016b)



represent the average of the oxygen isotope intake, rather than a single measurement of an oxygen isotope source (see e.g. Lightfoot and O'Connell 2016; Pellegrini et al. 2016). In addition to that, it is suggested that climatological/seasonal conditions have a significant influence on tap water $\delta^{18} \mathrm{O}$ values (Kennedy et al. 2011). As a result, for the purpose of this study, modern human $\delta^{18} \mathrm{O}_{\mathrm{PDB}}$ values $(-6.4$ to $4.6 \%$ ) were considered a more accurate representation of the average Dutch (drinking water) oxygen isotope composition. Nevertheless, all available converted $\delta^{18} \mathrm{O}$ values overlap with each other. Hence, based on all available (modern) baseline data, the $\delta^{18} \mathrm{O}_{\mathrm{DW}}$ isoscape map and the statistical analysis of the Oldenzaal oxygen isotope data, a conservative approach has been adopted, resulting in a local $\delta^{18} \mathrm{O}_{\mathrm{PDB}}$ signature range exhibiting values between -6.5 and $-4 \%$.

\section{Population diversity in terms of geographical origin}

An overview of the identified non-local individuals is given in Table 4 and Fig. 5. Based on the delineated local strontium isotope range (0.7091-0.7115), 13 individuals with non-local/ non-regional origins are identified (V700, V710, V1245, V1278, V1436, V1443, V1550, V2470, V2761, V2973, V3257, V3525 and V4037). These 13 non-local individuals possess assumed local $\delta^{18} \mathrm{O}_{\mathrm{PDB}}$ values, suggesting that they derived from regions with similar local $\delta^{18} \mathrm{O}$ values. Two individuals, V1694 and V2119, exhibit local strontium isotope ratios, but $\delta^{18} \mathrm{O}_{\mathrm{PDB}}$ values that are incompatible with the assumed local signal ( -7.3 and $-3.8 \%$, respectively). The 15 assumed foreign individuals ( $7.6 \%$ of the investigated population) represent nine males and six females. Two males
Table 2 Descriptive statistics of the ${ }^{87} \mathrm{Sr} /{ }^{86} \mathrm{Sr}$ and $\delta^{18} \mathrm{O}_{\mathrm{PDB}}$ data from Oldenzaal, the Netherlands $(n=\max 198)$

\begin{tabular}{llllll}
\hline & ${ }^{87} \mathrm{Sr}{ }^{86} \mathrm{Sr}$ & & & $\delta^{18} \mathrm{O}_{\mathrm{PDB}}$ & \\
\cline { 2 - 3 } Statistic & Complete & Trimmed ('local') & & Complete & Trimmed ('local') \\
\hline Count & 198 & 183 & & 188 & 187 \\
Mean & 0.71032 & 0.71031 & & -5.1 & -5.1 \\
Median & 0.71029 & 0.71029 & & -5.1 & -5.1 \\
Std. deviation & 0.00069 & 0.00053 & & 0.5 & 0.5 \\
Minimum & 0.70844 & 0.70910 & & -7.3 & -6.3 \\
Maximum & 0.71421 & 0.71152 & & -3.8 & -3.8 \\
Variance & $4.8 \mathrm{E}-07$ & $2.8 \mathrm{E}-07$ & & 0.3 & 0.2 \\
Skewness (SE) & $0.817(0.173)$ & $-0.112(0.178)$ & & $-0.491(0.177)$ & $-0.156(0.178)$ \\
Kurtosis (SE) & $5.114(0.344)$ & $-0.062(0.355)$ & & $1.001(0.353)$ & $-0.317(0.354)$ \\
\hline
\end{tabular}


Fig. 4 Histograms and Tukey's schematic boxplots showing ${ }^{87} \mathrm{Sr} /{ }^{86} \mathrm{Sr}$ variations for the complete dataset $(n=198)$ and the trimmed datasets $(n=1986$ and $n=183$, respectively). Key: the boxes represent the interquartile range (IQR: Q3-Q1), the central line indicates the median. The whiskers represent $\mathrm{Q} 1-1.5 \times \mathrm{IQR}$ and Q3 + $1.5 \times$ IQR. The circles represent outliers $(>1.5 \times \mathrm{IQR})$, the asterisks extreme outliers $(>3 \times \mathrm{IQR})$

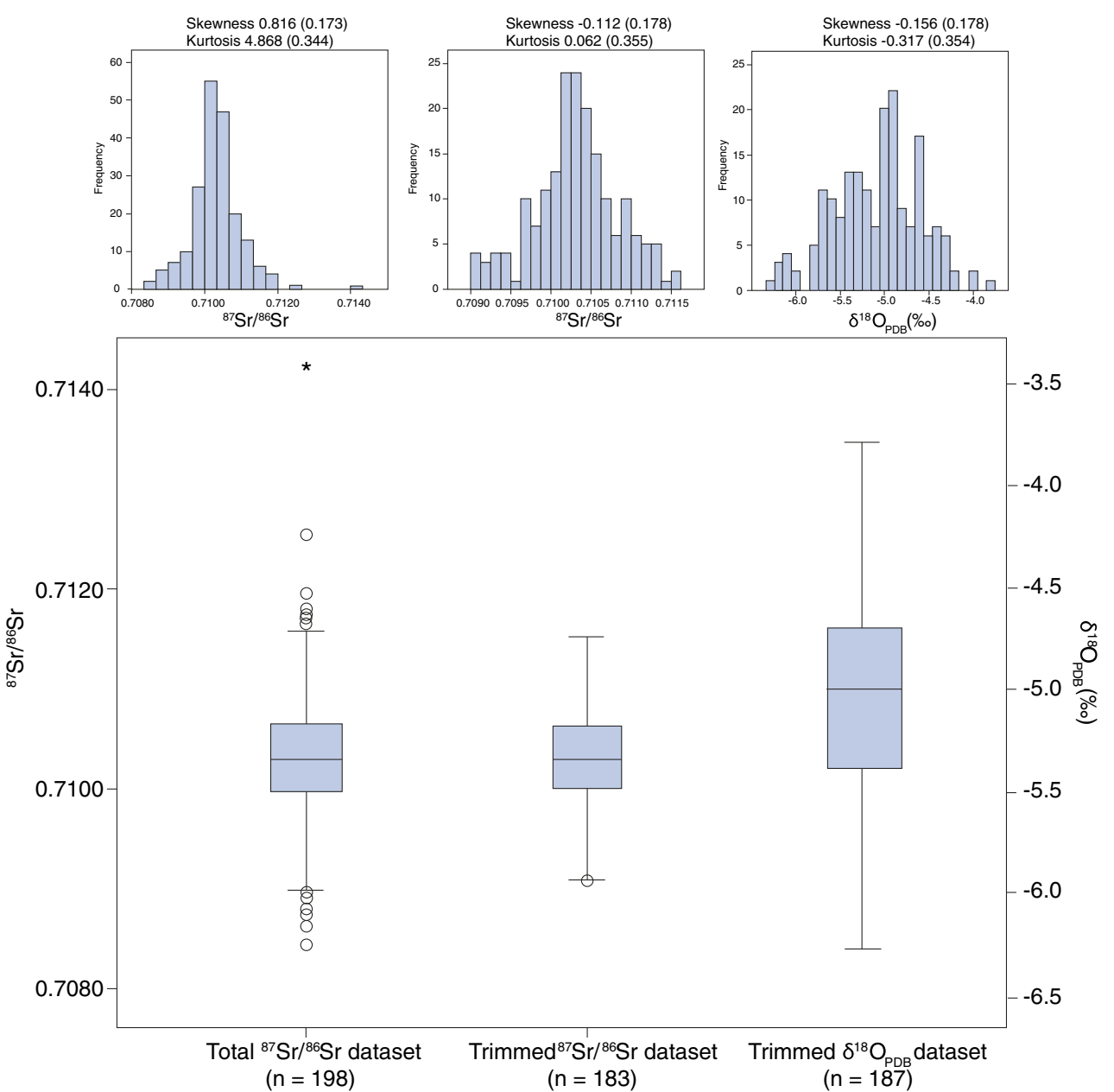

and three females date to the earliest period (AD $\sim 600-1500$, $n=5$ ). Seven males and two females are assigned to the later period, covering the years between AD 1500 and $1829(n=9)$. One non-local female could not be dated.

Seven of the non-locally born dwellers exhibit lower ${ }^{87} \mathrm{Sr} /{ }^{86} \mathrm{Sr}$ ratios than the expected minimal value $(0.7091)$, which translates into $3.5 \%$ of the investigated population. These values are characteristic of, for instance, the Dutch coastal and river areas (Kootker et al. 2016b). Six individuals
(3.0\%) originate from more radiogenic geological settings, characterised by values exceeding 0.7115 . Archaeological bioavailable strontium isotope ratios exceeding 0.7113 are not yet reported within the current Dutch borders. However, biosphere data from McManus et al. (2013) suggest that ratios as high as 0.716 are to be expected in areas where glacial sediments dominate the surface. Such regions (identified as isoscape $\mathrm{X}$ in Kootker et al. 2016b) are found within a 20-km radius around Oldenzaal. Hence, based on the available

Table 3 Overview of the available background and baseline $\delta^{18} \mathrm{O}$ data for the Netherlands

\begin{tabular}{|c|c|c|c|c|c|c|}
\hline Database/source & $n$ & $\delta^{18} \mathrm{O}$ with respect to & Minimum & Maximum & Average $\pm 1 \mathrm{SD}$ & Reference \\
\hline GNIP & & VSMOW & -9.2 & -5.1 & & IAEA/WMO 2016 \\
\hline $\begin{array}{l}\text { Modern human individuals from the } \\
\text { Netherlands }\end{array}$ & 30 & PDB & -6.4 & -4.6 & $-5.1 \pm 0.4^{*}$ & Font et al. 2015 \\
\hline $\begin{array}{l}\text { Modern tap water samples from the } \\
\text { Netherlands }\end{array}$ & 17 & VSMOW & $\mathrm{np}$ & $\mathrm{np}$ & $-7.0 \pm 1.1$ & Font et al. 2015 \\
\hline West-European $\delta^{18} \mathrm{O}_{\mathrm{DW}}$ isoscape map & & VSMOW & -7.5 & -6.0 & & $\begin{array}{l}\text { Darling et al. 2003; Lecolle 1985: } \\
\text { available at www.wessexarch.co. } \\
\text { uk/book/export/html/1672 }\end{array}$ \\
\hline
\end{tabular}

$n p$ data not published

*Excluding one statistical outlier 
Table 4 Overview of the assumed non-local individuals from Oldenzaal. The data on which the assumption is based are indicated in bold fonts

\begin{tabular}{|c|c|c|c|c|c|c|c|c|}
\hline \multirow{2}{*}{$\begin{array}{l}\text { ID } \\
\text { V0700 }\end{array}$} & \multirow{2}{*}{$\begin{array}{l}\text { Period } \\
2\end{array}$} & \multirow{2}{*}{$\begin{array}{l}\text { Biological sex } \\
\text { Male }\end{array}$} & \multicolumn{2}{|c|}{$\begin{array}{l}\text { Age at death } \\
\text { in years } \\
(\min -\max )\end{array}$} & \multirow{2}{*}{$\begin{array}{l}\begin{array}{l}\text { Dental } \\
\text { element }\end{array} \\
45\end{array}$} & \multirow{2}{*}{$\begin{array}{c}{ }^{87} \mathrm{Sr} /{ }^{86} \mathrm{Sr} \\
\mathbf{0 . 7 0 8 8 0}\end{array}$} & \multirow{2}{*}{$\begin{array}{l}2 \mathrm{SE} \\
0.00001\end{array}$} & \multirow{2}{*}{$\begin{array}{l}\delta^{18} \mathrm{O}_{\mathrm{PDB}}(\% \circ) \\
-5.4\end{array}$} \\
\hline & & & 22 & 45 & & & & \\
\hline V0710 & 2 & Male & 20 & 26 & 45 & 0.70896 & 0.00001 & -5.4 \\
\hline V1245 & 2 & Male & 20 & 25 & 36 & 0.71421 & 0.00001 & -5.4 \\
\hline V1278 & 2 & Male & 24 & 30 & 16 & 0.70897 & 0.00001 & -4.9 \\
\hline V1436 & 1 & Male & 20 & 25 & 16 & 0.70863 & 0.00001 & -5.4 \\
\hline V1443 & 2 & Male & 18 & 25 & 37 & 0.71196 & 0.00001 & -5.0 \\
\hline V1550 & 1 & Female & 31 & 36 & 26 & 0.71253 & 0.00001 & -4.9 \\
\hline V1694 & 2 & Male & 52 & 61 & 32 & 0.71071 & 0.00001 & -7.3 \\
\hline V2119 & 1 & Female & 28.5 & 33.5 & 36 & 0.70998 & 0.00001 & -3.8 \\
\hline V2470 & 2 & Female & 34 & 43 & 36 & 0.70844 & 0.00001 & -4.7 \\
\hline V2761 & 1 & Male & 25 & 34 & 42 & 0.71177 & 0.00001 & -4.9 \\
\hline V2973 & 1 & Female & 40 & 46 & 36 & 0.70899 & 0.00001 & -5.0 \\
\hline V3257 & 2 & Female & 20 & 34 & 35 & 0.71173 & 0.00001 & -5.8 \\
\hline V3524 & 2 & Male & 30 & 60 & 36 & 0.71180 & 0.00001 & -6.1 \\
\hline V4037 & 0 & Female & 41 & 47 & 46 & 0.70873 & 0.00001 & -4.7 \\
\hline
\end{tabular}

Period: 0, no period assigned; 1, AD 600-1500; 2, AD 1500-1829. Dental element: notation conforms to Fédération Dentaire Internationale (FDI: syntax: <quadrant code $><$ tooth code $>$ )
${ }^{87} \mathrm{Sr} /{ }^{86} \mathrm{Sr}$ baseline data, no unambiguous evidence is presented that large-distant migrants are present in the investigated sample. As the identification of a possible source of origin based on oxygen isotopes is challenging due to overlapping oxygen isotope ratios across different countries (see Lightfoot and O'Connell 2016; Pellegrini et al. 2016), and the absence of accurate baseline unconverted $\delta^{18} \mathrm{O}$ datasets, no attempt is made to provenance the two individuals that exhibit local ${ }^{87} \mathrm{Sr} /{ }^{86} \mathrm{Sr}$ ratios, but non-local $\delta^{18} \mathrm{O}_{\mathrm{PDB}}$ values.

\section{Infrastructural connectivity of Oldenzaal}

Information extracted from a variety of historical and infrastructural sources (for references, see below) show that
Oldenzaal was a hub connected to all major settlements in the region within both the early-medieval and early-modern route networks. Connections to and from the town also show a high level of route-network persistence between these two periods (Van Lanen et al. 2016, Fig. 6). The main reason is that past landscape dynamics in this region were limited, reducing the necessity to move route zones. In addition, network-friction calculations show that in this region only a few movement corridors suitable for routes existed, which significantly limited the options for route zones in this landscape. Based on these newly obtained route-network data, Oldenzaal must have been well-connected infrastructurally.

An ancient east-west route connecting Westphalia (Germany) to the western part of the Netherlands dissected
Fig. 5 Graphical presentation of the combined strontium and oxygen isotope data. The coloured bands mark the assumed local baseline ranges: 0.7091 0.7115 for strontium and -6.4 to $-4 \%$ for oxygen

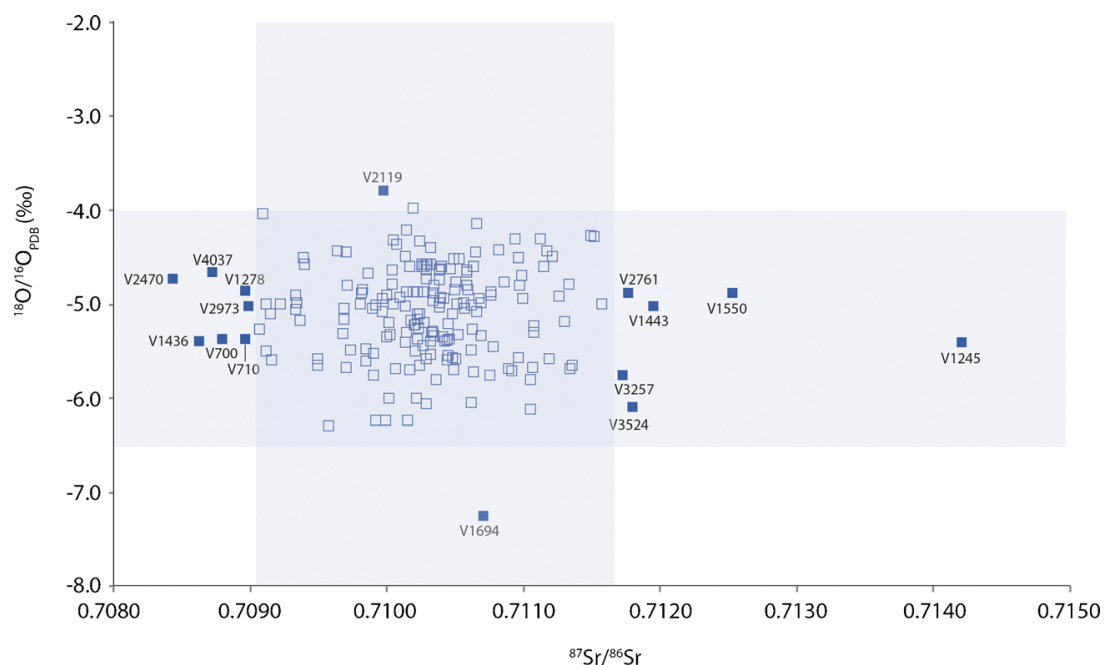






Fig. 6 Left-early-medieval route network (ca. AD 800) in the Netherlands adapted from Van Lanen et al. (2015a, b). Right - earlymodern land-route network (ca. AD 1600) adapted from Horsten

the Twente region, as did a north-south route of suggested prehistoric origin. Both routes became less significant from the thirteenth century onwards, coinciding with the development of more and better navigable inland waterways and with the introduction of larger cargo vessels (Rutte and Van Engen 2007). It is axiomatic for the study area that roads followed the landscape contours: they were primarily located on the higher, drier parts, and avoided wetlands, even though the latter were dissected by accessible corridors.

Long-distance connections of Oldenzaal within the context of its Hanseatic League membership appear to have been limited, or at least brief. League membership left no mark on the city's (economic) development, as is evidenced by the absence of a Hanseatic quarter with warehouses (Oude Nijhuis 2007). The presence of supraregional connections in Oldenzaal seems to have been largely restricted to the $\mathrm{AD}$ eleventh to fourteenth centuries. During this and subsequent periods, the main connections were oriented east-west. Solid historical evidence for Oldenzaal's Hanseatic activity is restricted to the late thirteenth and fourteenth centuries (Seyger 2005). Afterwards, the city's importance declined. With respect to trade, commerce and industry, Oldenzaal appears to have functioned as a regional centre and as a stop along the interregional trade routes running through the eastern Netherlands (Van Vliet 2002). Throughout its history, the city's significance as an ecclesiastical centre remained a dominant feature (Van Genabeek 2003).
AD 1600

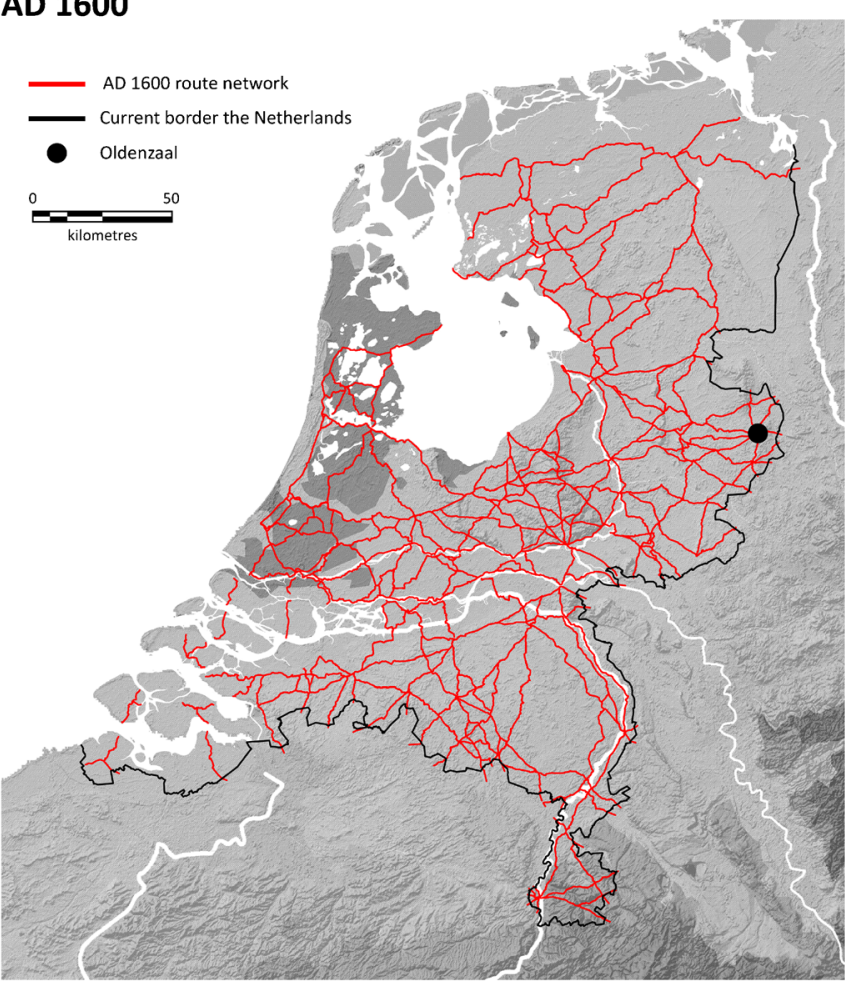

(2005). Together these networks depict the infrastructural connectivity of Oldenzaal during the studied time interval

The presence of multiple roads to and from Oldenzaal in the sixteenth-seventeenth century argues for a predominantly regional function of the town. By the end of the sixteenth century, the first Hessen-roads were established. These were key land routes that facilitated long-distance cargo transport to and from Germany (Fockema Andreae 1957). They connected large cities and in contrast to other types of routes avoided small, intermediate settlements. Two Hessen-roads between respectively Deventer and Zwolle to Paderborn in Germany (and further to Bremen, Hamburg and eventually Denmark) intersected Twente, but passed by Oldenzaal (Ligtenbarg and Spit 2010). This restricted the opportunities for the Oldenzaal region to further develop. It was not until the nineteenth century, when new roads, canals and train tracks were constructed, that Twente logistically became more advanced (Haartsen and Storms 2009).

\section{Discussion}

\section{Representativeness of the Oldenzaal isotope sample}

The process of sample selection can have sincere consequences for, and even significantly affect, the interpretation of isotopic data. In osteoarchaeological research, the complex relation between original living populations and excavated samples is well studied and understood. Biological, cultural 
and methodological factors may bias sample selection and hence analytical results (Hoppa 1996, 2001; Jackes 2011; Waldron 1994). It is safe to assume that these factors also affect the representativeness of the Oldenzaal sample. The individuals in this sample are from the north side and the edges of the cemetery, which might imply that this selection is biased towards the lower socio-economic classes of the population. Nonetheless, due to the large size of the sample ( $n=198)$, it is possible to infer meaningful information regarding palaeodemography, local background strontium and oxygen isotope values, and origin-related population dynamics. In addition, the use of statistics in all likelihood contributed to the selection of a sample that is as unbiased as possible (Jackes 2011). Nevertheless, it has to be taken into account that the results of the present study are directly connected to sample selection, and might have been different if sample selection had been based on different parameters.

\section{Reconstructing population variability}

Two factors related to the dataset and analytical methodology might have contributed significantly to the low observed degree of foreign influx. First, the dataset in all likelihood is biased, not representing the total population of Oldenzaal and its surroundings. A main reason is that with most churchyard excavations conducted outside the church walls, such as the excavations underlying the present study, two specific social groups are lacking or underrepresented: (1) the higher socio-economic classes and (2) the ecclesiastical class. The latter category presumably represented circa $5 \%$ of the Medieval population in Oldenzaal (estimation based on Bove and Gauvard 2014; Broadberry et al. 2010; Pirenne 2014). Usually, ecclesiastical authorities were buried in the church, or within the walls of their monastic properties (Ostkamp 1999). Given the ecclesiastical significance of Oldenzaal and the fact that in particular high-ranking officials of clerical institutions often originated from more distant regions, these potentially non-locally born inhabitants of Oldenzaal probably are underrepresented in the selection. Hence, the analysed sample probably only represents 'ordinary' citizens of the Oldenzaal region, who did not hold specific higher ecclesiastical and/or social positions. Second, interpretative limitations hamper an accurate assessment of population dynamism. Through the use of strontium and oxygen isotope systems, non-locally born individuals can be identified, enabling a first insight into residential mobility. This interpretation of the data, however, heavily depends on the defined local strontium and oxygen isotopes baseline values. Baseline strontium isotope values are established for several countries in Europe (e.g. Evans et al. 2009, 2010; Frei and Frei 2011; Willmes et al. 2014), and are subject to constant (methodological) improvement (Laffoon et al. 2017). Moreover, strontium passes from bedrock to the soil to bioavailable solutions to our skeleton without measurable isotopic fractionation (see Bentley 2006), and the interpretation of ${ }^{87} \mathrm{Sr} /{ }^{86} \mathrm{Sr}$ data does not require conversion steps. This is not the case for the oxygen isotope system. Baseline datasets containing unconverted oxygen isotope data are scarce; metabolic processes alter the ratio ${ }^{18} \mathrm{O}$ to ${ }^{16} \mathrm{O}$ within our skeletal material; natural processes influence the $\delta^{18} \mathrm{O}$ value of water sources and errors up to circa $1-3.5 \%$ are introduced by the application of conversion equations to transform measured $\delta^{18} \mathrm{O}$ to drinking water $\delta^{18} \mathrm{O}$ values (Chenery et al. 2012; Pollard et al. 2011; Wright and Schwarcz 1998). To avoid the potential offset introduced by the conversion equations, in this study, only unconverted $\delta^{18} \mathrm{O}$ data was presented and a first attempt was made to define a local $\delta^{18} \mathrm{O}_{\mathrm{PDB}}$ range as accurate as possible. This range will unquestionably be subject to future refinement. The applied methodologies, therefore, must be considered as predominantly exclusive, since it only allows the identification of non-locally born individuals exhibiting extreme isotopic values beyond the expected local or national baseline range. To date, both applied isotope systems do not result in powerful markers for accurate provenancing, due to, amongst other factors, the absence of a single, uniform European isoscape map for each isotope system. As a result, the reconstruction of population variability in Oldenzaal is as accurate as the methods the reconstruction is based upon (see also Laffoon et al. 2017). Future reassessment of the data presented here employing more improved strontium and oxygen isotope baseline datasets might result in a reinterpretation of the results, and the extent of population variability in Medieval Oldenzaal.

\section{Palaeodemography versus infrastructural connections}

Although these analytical limitations provide us with reasonable explanations for the strontium and oxygen isotope data, the question arises to what extent natural and socio-cultural factors also have influenced the results. Factors such as Oldenzaal's level of infrastructural connectivity, its location within specific transport networks such as the Hanseatic league and the persistency of route networks in the Twente region might have had a significant effect on the ability of people to travel to and from Oldenzaal in the earliest studied period (AD 600-1500).

The high degree in which Oldenzaal was connected infrastructurally probably did not lead to an increased influx of non-local individuals. This is best explained by two sociocultural factors. The first factor is the dominantly regional importance of the town. Our research shows that during most of its existence, Oldenzaal was a centre of commerce and trade of regional importance only. Interregional (east-west) connections were limited and only of some importance between the AD eleventh and fourteenth century. The prevalence of individuals from isotopically different regions, specifically the coastal clay areas of the western Netherlands, northern Germany, Denmark 
and riverine areas (such as the nearby 'Hanseatic' IJssel valley), is low. Most eleventh-twelfth century traders probably did not travel very far, did not settle permanently and/or might have grown up in areas that exhibit isotope profiles similar to the Twente region, such as Westphalia. This connection between Oldenzaal and isotopically similar regions is underlined by the results of dendrochronological research of wooden structures in Oldenzaal, amongst other the St. Plechelm church, which all point towards wood being imported by land from the low-lying plains in adjacent Germany, mainly from Westphalia north of the river Rhine (see supplementary data). Second, although through time Oldenzaal may have been an integral part of active interregional route networks, this does not imply that many people from far away came to Oldenzaal to become permanent inhabitants. Apparently, a high level of infrastructural connectivity does not necessarily bring about a high level of population variability. Broader socio-cultural factors appear to have been of crucial importance in the formation of route networks and population structure. This was already suggested by Van Lanen and Pierik (2017) for the Rhine-Meuse delta in the Netherlands. They concluded that the concept of connectivity patterns, which they define as the dynamic spatial and social interrelation and interaction between past landscapeinfluencing factors, settlement patterns, land use, route networks, long-distance transport routes, physical-landscape formation processes and demography, are crucial to understand past human-landscape interactions. Factors within this system are of continuous path-dependent influence on one another, and changes in individual factors may cause far-reaching effects in other connected factors. Moreover, during the Late Middle Ages, the city of Oldenzaal seems to have been rather reticent in the granting of citizenship (Weustink 1962), further hampering the influx of non-locally born individuals. Therefore, in order to fully understand palaeodemographics and population variability, a broader comparative study of connectivity patterns within the Netherlands and on a European scale is required. In addition, the interpretation of local versus non-local percentages within local populations would benefit from the availability of a more extensive frame of reference, consisting of more comparable datasets.

\section{Oldenzaal's infrastructural connections compared to the origin of its inhabitants}

The hypothesis of this study was that the degree in which Oldenzaal in the past was connected to other regions also must be expressed by the geographical origin of its former population. Therefore, based on Oldenzaal's high level of connectivity, a relatively diverse range in strontium and oxygen isotope ratios was expected due to the influx of foreigners. Data from both comparison periods, AD 600-1500 and AD 1500-1829, show a comparably low number of individuals of possibly non-local origin.
Although non-contemporaneous isotope data from pioneering, dynamic populations in the Netherlands obtained to date show $>40 \%$ of residential mobility (e.g. Kootker 2014; Kootker et al. 2017), in Oldenzaal no more than $7.8 \%$ of the investigated population might have been of non-local origin. This number, however, actually represents the absolute minimum number of migrants, as nonlocals who originated from areas with identical isotope values remain isotopically invisible (see also Pellegrini et al. 2016). Hence, the data presented here point towards a population characterised by a low influx of nonindigenous people and/or a population characterised by influx of non-local people primarily from isotopic identical source regions. Moreover, the low number of relatively low ${ }^{87} \mathrm{Sr} /{ }^{86} \mathrm{Sr}$ ratios is quite characteristic, particularly since these values are representative of $>45 \%$ of the surface of the present-day Netherlands, and also occur regions in relatively close proximity, and infrastructurally wellconnected, to Oldenzaal $(80-100 \mathrm{~km}$, Kootker et al. 2016b). This implies that even from these relatively nearby areas (where major Hanseatic trading centres were situated), hardly any migration to Oldenzaal occurred during the studied time interval of $>1000$ years.

\section{Conclusion}

The aim of this study was to assess whether the degree in which Oldenzaal was connected to the outside world in the past is also expressed by the quantitative degree of variability in terms of the geographical origin of its former population. This question builds on the hypothesis that well-connected settlements can be expected to be demographically more diverse and dynamic in terms of origin than poorly connected settlements. The data suggest that the influx of non-local people in Oldenzaal during $>1000$ years was consistently low, despite the fact that Oldenzaal was infrastructurally well-connected, and therefore easily accessible. We acknowledge, however, that the interpretation of the obtained isotope data is heavily controlled by the quality of the available reference isotope datasets. Unconverted $\delta^{18} \mathrm{O}$ baseline data is to date scarce, and established baseline datasets or isoscapes are subject to continuous improvement. As a result, future reassessment of the Oldenzaal data might result in a different, and probably a more accurate outcome. The generated $\delta^{18} \mathrm{O}_{\mathrm{PDB}}$ data, however, provide a valuable reference dataset.

In conclusion, this research shows that the presence of well-connected communication and transport networks alone was not a determining factor in the cultivation of a receptive environment for immigrants; i.e. the strong influence of broader socio-cultural factors on palaeodemographics demonstrate the necessity of integrated, multi- and transdisciplinary research approaches towards studying populations in the past. 
Acknowledgements The archaeological excavation was conducted by ADC ArcheoProjecten in collaboration with RAAP Archeologisch Adviesbureau. The excavation and the extensive bioarchaeological investigations were financed by the municipality of Oldenzaal ( $€ 300 \mathrm{~K})$ and the Cultural Heritage Agency (RCE: special-purpose grant $(€ 1.6 \mathrm{M})$ Regeling specifieke uitkeringen excessieve opgravingskosten conform section 34 of the former Monuments and Historic Buildings Act 1988). Gavin Williams (ADC Archeoprojecten) is thanked for his comments on an earlier draft of this paper. Susan Verdegaal-Warmerdam and her team (Vrije Universiteit Amsterdam) are thanked for the prompt generation of oxygen isotopic data. EA thanks Risha Smeding, Eileen Vaske and Paul Reusink (Department of
Human Genetics, Leiden University Medical Centre) for assistance, and prof. dr. Peter de Knijff (ibid.) for providing facilities. We thank two anonymous reviewers for their helpful comments.

Funding information The TRITON facility at the Vrije Universiteit Amsterdam is funded by the Netherlands Organisation for Scientific Research (NWO - grant no. 834.10.001). Funding for RJvL and GRD is provided by NWO (grant no. 360.60.110) and the European Union's Seventh Framework Programme (FP7/2007-2013) / ERC Synergy (grant no. 319209), respectively.

\section{Appendix}

Table 5 Archaeological data, biological sex, age at death, ${ }^{87} \mathrm{Sr} /{ }^{86} \mathrm{Sr}$ and $\delta^{18} \mathrm{O}$ data from 198 individuals from Oldenzaal, the Netherlands

\begin{tabular}{|c|c|c|c|c|c|c|c|c|c|c|c|c|}
\hline \multirow{2}{*}{$\begin{array}{l}\text { ID } \\
\text { V0218 }\end{array}$} & \multirow{2}{*}{$\begin{array}{l}\text { Feature } \\
136\end{array}$} & \multirow{2}{*}{$\begin{array}{c}\text { Zone } \\
\mathrm{A}\end{array}$} & \multirow{2}{*}{$\begin{array}{l}\text { Period } \\
2\end{array}$} & \multirow{2}{*}{$\begin{array}{l}\begin{array}{l}\text { Biological } \\
\text { sex }\end{array} \\
\text { Male }\end{array}$} & \multicolumn{2}{|c|}{$\begin{array}{l}\text { Age at death in } \\
\text { years (min-max) }\end{array}$} & \multirow{2}{*}{$\begin{array}{l}\begin{array}{l}\text { Dental } \\
\text { element }\end{array} \\
16\end{array}$} & \multirow{2}{*}{$\begin{array}{l}{ }^{87} \mathrm{Sr} /{ }^{86} \mathrm{Sr} \\
0.709847\end{array}$} & \multirow{2}{*}{$\begin{array}{l}2 \mathrm{SE} \\
0.000008\end{array}$} & \multirow{2}{*}{$\frac{\delta^{18} \mathrm{O}_{\mathrm{PDB}}}{-5.5}$} & \multirow{2}{*}{$\begin{array}{l}\delta^{18} \mathrm{O}_{\mathrm{SMOW}} \\
25.3\end{array}$} & \multirow{2}{*}{$\frac{\delta^{18} \mathrm{O}_{\mathrm{DW}}}{-8.5}$} \\
\hline & & & & & 41.75 & 46.75 & & & & & & \\
\hline V0256 & 139 & A & 2 & Male & 34 & 43 & 43 & 0.710511 & 0.000012 & -5 & 25.8 & -7.7 \\
\hline V0449 & 230 & A & 1 & Female & 34 & 40 & 14 & 0.710584 & 0.00001 & -4.6 & 26.1 & -7.1 \\
\hline V0470 & 237 & $\mathrm{C}$ & 2 & Female & 20 & 50 & 36 & 0.709073 & 0.000008 & -5.3 & 25.5 & -8.1 \\
\hline V0489 & 239 & $\mathrm{C}$ & 2 & Male & 50 & 65 & 34 & 0.709573 & 0.00001 & -6.3 & 24.4 & -9.8 \\
\hline V0490 & 240 & $\mathrm{C}$ & 2 & Male & 42.33 & 48.33 & 26 & 0.70974 & 0.00001 & -5.5 & 25.3 & -8.5 \\
\hline V0561 & 254 & $\mathrm{C}$ & 0 & Female & 32 & 50 & 25 & 0.710386 & 0.000012 & -4.6 & 26.1 & -7.1 \\
\hline V0573 & 264 & $\mathrm{C}$ & 0 & Male & 35 & 45 & 46 & 0.710964 & 0.000008 & -4.5 & 26.3 & -6.9 \\
\hline V0600 & 253 & $\mathrm{C}$ & 1 & Male & 22 & 80 & 46 & 0.710977 & 0.000009 & -4.8 & 26 & -7.4 \\
\hline V0602 & 258 & $\mathrm{C}$ & 1 & Female & 40 & 70 & 36 & 0.709338 & 0.000009 & -4.9 & 25.9 & -7.5 \\
\hline V0603 & 256 & $\mathrm{C}$ & 2 & Male & 39 & 45 & 43 & 0.709224 & 0.00001 & -5 & 25.8 & -7.7 \\
\hline V0631 & 252 & $\mathrm{C}$ & 2 & Male & 24 & 33.5 & 36 & 0.711341 & 0.000009 & -5.7 & 25 & -8.8 \\
\hline V0700 & 369 & A & 2 & Male & 22 & 45 & 45 & 0.708795 & 0.00001 & -5.4 & 25.4 & -8.3 \\
\hline V0710 & 255 & $\mathrm{C}$ & 2 & Male & 20 & 26 & 45 & 0.708963 & 0.000011 & -5.4 & 25.4 & -8.3 \\
\hline V0781 & 415 & A & 1 & Male & 20 & 34 & 44 & 0.710569 & 0.000008 & -5 & 25.7 & -7.8 \\
\hline V0863 & 424 & A & 2 & Female & 30 & 60 & 47 & 0.710211 & 0.00001 & -5.5 & 25.2 & -8.5 \\
\hline V0865 & 10 & A & 2 & Male & 52 & 61 & 36 & 0.710181 & 0.000009 & -5.2 & 25.6 & -8 \\
\hline V0870 & 422 & A & 2 & Male & 53.3 & 59.3 & 46 & 0.709121 & 0.000008 & -5.5 & 25.2 & -8.5 \\
\hline V0899 & 469 & A & 2 & Male & 43 & 55 & 46 & 0.710445 & 0.000008 & -5.6 & 25.1 & -8.7 \\
\hline V0902 & 433 & $\mathrm{C}$ & 2 & Female & 32.67 & 38.67 & 33 & 0.710027 & 0.000009 & -5.3 & 25.4 & -8.2 \\
\hline V0922 & 505 & A & 1 & Male & 52 & 61 & $23 ?$ & 0.709704 & 0.000008 & -5.7 & 25.1 & -8.8 \\
\hline V1100 & 15 & A & 2 & Female & 36 & 42 & 13 & 0.710817 & 0.00001 & -4.4 & 26.3 & -6.7 \\
\hline V1101 & 26 & A & 2 & Female & 30 & 36 & 46 & 0.710168 & 0.000016 & -5.7 & 25 & -8.8 \\
\hline V1104 & 28 & A & 2 & Male & 31.5 & 36.5 & 34 & 0.711301 & 0.000009 & -5.2 & 25.6 & -8 \\
\hline V1105 & 544 & A & 0 & Male & 40 & 46 & 46 & 0.71136 & 0.000008 & -5.7 & 25.1 & -8.8 \\
\hline V1123 & 29 & A & 2 & Female & 42.3 & 48.3 & 16 & 0.710658 & 0.00001 & -5.1 & 25.7 & -7.8 \\
\hline V1147 & 552 & A & 2 & Female & 40 & 46 & 46 & 0.70982 & 0.000009 & -4.9 & 25.9 & -7.5 \\
\hline V1155 & 553 & $\mathrm{C}$ & 0 & NTD & 18 & 80 & 36 & 0.711576 & 0.000011 & -5 & 25.8 & -7.7 \\
\hline V1166 & 562 & A & 1 & NTD & 9.5 & 14.5 & 36 & 0.710289 & 0.00001 & -4.6 & 26.2 & -7 \\
\hline V1174 & 536 & $\mathrm{C}$ & 0 & Male & 14 & 18 & 46 & 0.710038 & 0.00001 & -4.8 & 26 & -7.3 \\
\hline V1193 & 37 & $\mathrm{E}$ & 2 & Male & 20 & 30 & 36 & 0.710137 & 0.00001 & -5 & 25.7 & -7.7 \\
\hline V1201 & 568 & A & 1 & Male & 35 & 52 & 33 & 0.709147 & 0.00001 & -5.1 & 25.7 & -7.8 \\
\hline
\end{tabular}


Table 5 (continued)

\begin{tabular}{|c|c|c|c|c|c|c|c|c|c|c|c|c|}
\hline ID & Feature & Zone & Period & $\begin{array}{l}\text { Biological } \\
\text { sex }\end{array}$ & $\begin{array}{l}\text { Age at } \\
\text { years }\end{array}$ & $\begin{array}{l}\text { ath in } \\
1-\max )\end{array}$ & $\begin{array}{l}\text { Dental } \\
\text { element }\end{array}$ & ${ }^{87} \mathrm{Sr} /{ }^{86} \mathrm{Sr}$ & $2 \mathrm{SE}$ & $\delta^{18} \mathrm{O}_{\mathrm{PDB}}$ & $\delta^{18} \mathrm{O}_{\text {SMOW }}$ & $\delta^{18} \mathrm{O}_{\mathrm{DW}}$ \\
\hline V1214 & 629 & A & 1 & Female & 11 & 15 & 27 & 0.710151 & 0.000011 & -6.2 & 24.5 & -9.7 \\
\hline V1215 & 572 & A & 1 & Male & 1.4 & 2.6 & 63 & 0.710062 & 0.000007 & - & - & - \\
\hline V1229 & 569 & $\mathrm{~A}$ & 1 & Female & 34 & 40 & 46 & 0.710623 & 0.00001 & -5 & 25.7 & -7.7 \\
\hline V1233 & 570 & $\mathrm{~A}$ & 1 & Male & 15 & 20 & 16 & 0.709116 & 0.000014 & -5 & 25.8 & -7.7 \\
\hline V1237 & 573 & $\mathrm{~A}$ & 0 & Male & & & 24 & 0.710944 & 0.000008 & -4.3 & 26.5 & -6.6 \\
\hline V1245 & 40 & $\mathrm{E}$ & 2 & Male & 20 & 25 & 36 & 0.714209 & 0.000008 & -5.4 & 25.3 & -8.4 \\
\hline V1274 & 575 & $\mathrm{~A}$ & 1 & Female & 3 & 5 & 84 & 0.709804 & 0.000008 & - & - & - \\
\hline V1278 & 50 & $\mathrm{~A}$ & 2 & Male & 24 & 30 & 16 & 0.708969 & 0.000009 & -4.9 & 25.9 & -7.5 \\
\hline V1282 & 577 & A & 1 & Female & 20 & 25 & 16 & 0.70992 & 0.00001 & -6.2 & 24.5 & -9.7 \\
\hline V1286 & 574 & $\mathrm{~A}$ & 1 & Female & 4 & 8 & 54 & 0.710964 & 0.000008 & - & - & - \\
\hline V1293 & 579 & $\mathrm{~A}$ & 1 & Male & 34 & 43 & 36 & 0.709396 & 0.000008 & -4.6 & 26.2 & -7 \\
\hline V1297 & 51 & $\mathrm{~A}$ & 2 & Female & 40 & 46 & 36 & 0.710005 & 0.000009 & -5.3 & 25.4 & -8.3 \\
\hline V1307 & 641 & $\mathrm{~A}$ & 1 & Female & 6 & 9 & 26 & 0.710689 & 0.00001 & -5 & 25.8 & -7.7 \\
\hline V1320 & 642 & $\mathrm{~A}$ & 1 & Male & 20 & 25 & 46 & 0.710625 & 0.000008 & -5.3 & 25.5 & -8.1 \\
\hline V1350 & 61 & $\mathrm{~A}$ & 1 & Male & 8 & 10 & 26 & 0.710299 & 0.000008 & -4.6 & 26.2 & -7 \\
\hline V1376 & 654 & $\mathrm{~A}$ & 2 & Male & 6 & 10 & 36 & 0.709677 & 0.000009 & -5.3 & 25.4 & -8.2 \\
\hline V1388 & 669 & A & 1 & Male & 31.33 & 37.33 & 36 & 0.710257 & 0.000008 & -4.6 & 26.2 & -7 \\
\hline V1400 & 655 & $\mathrm{~A}$ & 1 & Female & 30 & 60 & 34 & 0.709158 & 0.000009 & -5.6 & 25.1 & -8.7 \\
\hline V1408 & 660 & A & 1 & Female & 25 & 34 & 26 & 0.710763 & 0.000009 & -4.9 & 25.9 & -7.5 \\
\hline V1416 & 663 & $\mathrm{~A}$ & 1 & Female & 15 & 18 & 35 & 0.710488 & 0.000008 & -5.7 & 25 & -8.8 \\
\hline V1420 & 656 & $\mathrm{~A}$ & 1 & Male & 15 & 18 & 16 & 0.710206 & 0.000009 & -5.2 & 25.5 & -8 \\
\hline V1435 & 653 & $\mathrm{~A}$ & 1 & Female & 36 & 42 & 16 & 0.710272 & 0.000009 & -4.6 & 26.2 & -7 \\
\hline V1436 & 673 & $\mathrm{~A}$ & 1 & Male & 20 & 25 & 16 & 0.708629 & 0.000008 & -5.4 & 25.4 & -8.3 \\
\hline V1443 & 69 & $\mathrm{~A}$ & 2 & Male & 18 & 25 & 37 & 0.711955 & 0.000008 & -5 & 25.7 & -7.7 \\
\hline V1454 & 680 & A & 1 & Female & 51 & 56 & 26 & 0.709967 & 0.00001 & -4.9 & 25.8 & -7.6 \\
\hline V1476 & 89 & $\mathrm{~A}$ & 2 & Female & 36 & 54 & 46 & 0.710783 & 0.000009 & -5.4 & 25.3 & -8.4 \\
\hline V1484 & 119 & $\mathrm{~A}$ & 1 & Female & 20 & 30 & 36 & 0.710509 & 0.000009 & -4.8 & 26 & -7.3 \\
\hline V1488 & 96 & $\mathrm{~A}$ & 2 & Female & 35 & 44 & 16 & 0.710385 & 0.000008 & -4.6 & 26.1 & -7.1 \\
\hline V1509 & 98 & $\mathrm{~A}$ & 2 & Male & 7 & 9 & 46 & 0.710211 & 0.000006 & -5.2 & 25.5 & -8 \\
\hline V1513 & 699 & A & 1 & Female & 20 & 25 & 36 & 0.710288 & 0.000009 & -6.1 & 24.7 & -9.4 \\
\hline V1517 & 697 & A & 1 & Female & 18 & 29 & 26 & 0.711128 & 0.000011 & -4.3 & 26.5 & -6.5 \\
\hline V1521 & 691 & $\mathrm{~A}$ & 0 & Male & 14 & 18 & 34 & 0.710384 & 0.000012 & -4.7 & 26 & -7.3 \\
\hline V1550 & 106 & A & 1 & Female & 31 & 36 & 26 & 0.712533 & 0.000009 & -4.9 & 25.9 & -7.5 \\
\hline V1584 & 115 & $\mathrm{~A}$ & 1 & Female & 30 & 36 & 36 & 0.710467 & 0.000008 & -4.6 & 26.1 & -7.1 \\
\hline V1585 & 116 & $\mathrm{~A}$ & 1 & Female & 30 & 36 & 44 & 0.710459 & 0.00001 & -5.4 & 25.4 & -8.3 \\
\hline V1618 & 708 & $\mathrm{C}$ & 1 & Female & 15 & 25 & 46 & 0.71059 & 0.000006 & -4.8 & 26 & -7.4 \\
\hline V1673 & 748 & $\mathrm{~A}$ & 1 & Female & 15 & 23 & 36 & 0.709347 & 0.000008 & -5 & 25.8 & -7.7 \\
\hline V1675 & 754 & $\mathrm{C}$ & 0 & Female & 15 & 20 & 12 & 0.710239 & 0.000008 & -5.7 & 25.1 & -8.8 \\
\hline V1682 & 751 & A & 1 & Male & 20 & 80 & 36 & 0.711053 & 0.00001 & -6.1 & 24.6 & -9.5 \\
\hline V1694 & 4 & $\mathrm{E}$ & 2 & Male & 52 & 61 & 32 & 0.710707 & 0.000011 & -7.3 & 23.4 & -11.4 \\
\hline V1749 & 12 & $\mathrm{E}$ & 2 & Female & 20 & 29 & 25 & 0.710323 & 0.000011 & -5.5 & 25.2 & -8.6 \\
\hline V1812 & 801 & A & 1 & Male & 15 & 20 & 36 & 0.709688 & 0.000008 & -5 & 25.7 & -7.8 \\
\hline V1855 & 34 & $\mathrm{E}$ & 2 & Female & 44 & 52 & 14 & 0.710341 & 0.000009 & -4.9 & 25.9 & -7.5 \\
\hline V1863 & 804 & A & 1 & Female & 19 & 28 & 46 & 0.710766 & 0.000008 & -4.9 & 25.9 & -7.5 \\
\hline V1879 & 32 & $\mathrm{E}$ & 2 & Female & 3 & 5 & 16 & 0.710222 & 0.000008 & -6 & 24.7 & -9.3 \\
\hline V1887 & 51 & $\mathrm{E}$ & 2 & Female & 61 & 66 & 34 & 0.710232 & 0.00001 & -5.3 & 25.5 & -8.1 \\
\hline V1901 & 828 & $\mathrm{~A}$ & 1 & Male & 28.5 & 33.5 & 37 & 0.710441 & 0.000009 & -5.4 & 25.4 & -8.3 \\
\hline V1928 & 67 & $\mathrm{E}$ & 1 & Male & 41.3 & 46.3 & 47 & 0.710481 & 0.000008 & -5.6 & 25.2 & -8.6 \\
\hline
\end{tabular}


Table 5 (continued)

\begin{tabular}{|c|c|c|c|c|c|c|c|c|c|c|c|c|}
\hline ID & Feature & Zone & Period & $\begin{array}{l}\text { Biological } \\
\text { sex }\end{array}$ & $\begin{array}{l}\text { Age } \\
\text { years }\end{array}$ & $\begin{array}{l}\text { th in } \\
1-\max )\end{array}$ & $\begin{array}{l}\text { Dental } \\
\text { element }\end{array}$ & ${ }^{87} \mathrm{Sr} /{ }^{86} \mathrm{Sr}$ & 2SE & $\delta^{18} \mathrm{O}_{\mathrm{PDB}}$ & $\delta^{18} \mathrm{O}_{\text {SMOW }}$ & $\delta^{18} \mathrm{O}_{\mathrm{DW}}$ \\
\hline V1983 & 74 & E & 2 & Male & 40 & 44 & 46 & 0.710255 & 0.000008 & -4.6 & 26.2 & -7 \\
\hline V1990 & 164 & A & 1 & Female & 28 & 35 & 44 & 0.710291 & 0.000009 & -4.7 & 26 & -7.2 \\
\hline V2003 & 851 & A & 1 & Male & 6 & 10 & 36 & 0.711075 & 0.000008 & -5.3 & 25.4 & -8.2 \\
\hline V2017 & 16 & A & 2 & Female & 17 & 21 & 46 & 0.710333 & 0.00001 & -5.3 & 25.4 & -8.2 \\
\hline V2057 & 76 & E & 2 & Female & 15 & 20 & 46 & 0.710077 & 0.000007 & -4.4 & 26.4 & -6.6 \\
\hline V2061 & 165 & $\mathrm{~A}$ & 1 & Male & 49.3 & 54.3 & 46 & 0.709822 & 0.000009 & -4.8 & 25.9 & -7.4 \\
\hline V2064 & 19 & A & 1 & Female & 40 & 46 & 46 & 0.710338 & 0.000008 & -5.3 & 25.5 & -8.2 \\
\hline V2076 & 852 & A & 1 & Female & 30 & 36 & 46 & 0.710242 & 0.000007 & -5.1 & 25.7 & -7.8 \\
\hline V2102 & 80 & E & 1 & Male & 34 & 40 & 14 & 0.710976 & 0.000008 & - & - & - \\
\hline V2119 & 22 & A & 1 & Female & 28.5 & 33.5 & 36 & 0.709976 & 0.000008 & -3.8 & 27 & -5.7 \\
\hline V2127 & 24 & A & 2 & Male & 30 & 60 & 34 & 0.71 & 0.00001 & -4.9 & 25.9 & -7.5 \\
\hline V2181 & 91 & E & 1 & Female & 12 & 15 & 46 & 0.710275 & 0.000009 & -4.9 & 25.9 & -7.5 \\
\hline V2196 & 29 & A & 2 & Female & 20 & 25 & 46 & 0.710992 & 0.000009 & - & - & - \\
\hline V2205 & 34 & $\mathrm{~A}$ & 2 & Female & 40 & 46 & 16 & 0.71105 & 0.000008 & -5.8 & 24.9 & -9 \\
\hline V2223 & 96 & E & 1 & NTD & 3 & 6 & 45 & 0.710388 & 0.000011 & -5 & 25.7 & -7.7 \\
\hline V2238 & 98 & E & 1 & Male & 46 & 52 & 46 & 0.709095 & 0.000008 & -4 & 26.7 & -6.1 \\
\hline V2268 & 47 & A & 1 & Male & 12 & 18 & 35 & 0.711001 & 0.000007 & -4.9 & 25.8 & -7.6 \\
\hline V2293 & 54 & A & 0 & Male & 60 & 70 & 26 & 0.711216 & 0.000008 & -4.5 & 26.3 & -6.9 \\
\hline V2318 & 61 & A & 1 & NTD & 9.5 & 13.5 & 46 & 0.710228 & 0.000009 & -5.4 & 25.4 & -8.3 \\
\hline V2362 & 70 & A & 1 & Female & 43 & 60 & 36 & 0.710267 & 0.000009 & -5.4 & 25.3 & -8.4 \\
\hline V2367 & 68 & A & 2 & Female & 60 & 70 & 35 & 0.71035 & 0.000008 & -5.3 & 25.4 & -8.2 \\
\hline V2379 & 109 & E & 1 & Female & 35 & 55 & 35 & 0.711076 & 0.000009 & -5.2 & 25.5 & -8.1 \\
\hline V2399 & 75 & A & 1 & Female & 30 & 36 & 35 & 0.709395 & 0.000008 & -4.5 & 26.3 & -6.9 \\
\hline V2470 & 89 & $\mathrm{~A}$ & 2 & Female & 34 & 43 & 36 & 0.708436 & 0.000008 & -4.7 & 26 & -7.2 \\
\hline V2503 & 105 & A & 0 & Female & 7 & 11 & 43 & 0.711492 & 0.000011 & -4.3 & 26.5 & -6.5 \\
\hline V2554 & 123 & A & 0 & Female & 35 & 55 & 36 & 0.710364 & 0.000011 & -5.8 & 24.9 & -9 \\
\hline V2558 & 124 & A & 1 & Male & 7 & 11 & 16 & 0.709867 & 0.000008 & -4.7 & 26.1 & -7.1 \\
\hline V2643 & 147 & A & 1 & Female & 50 & 59 & 46 & 0.710246 & 0.00001 & -4.3 & 26.4 & -6.6 \\
\hline V2686 & 158 & A & 1 & Male & 2 & 3 & 62 & 0.709743 & 0.000012 & - & - & - \\
\hline V2729 & 167 & A & 1 & Female & 10 & 15 & 45 & 0.711521 & 0.000009 & -4.3 & 26.5 & -6.5 \\
\hline V2737 & 169 & A & 1 & Female & 18 & 25 & 46 & 0.71029 & 0.000011 & -4.6 & 26.1 & -7.1 \\
\hline V2748 & 176 & A & 1 & Female & 34 & 40 & 46 & 0.709364 & 0.000009 & -5.2 & 25.6 & -8 \\
\hline V2761 & 876 & A & 1 & Male & 25 & 34 & 42 & 0.71177 & 0.000009 & -4.9 & 25.9 & -7.5 \\
\hline V2811 & 2 & E & 2 & Male & 40 & 49 & 44 & 0.709336 & 0.000009 & -5.1 & 25.7 & -7.8 \\
\hline V2812 & 1 & E & 2 & Female & 25 & 34 & $16 ?$ & 0.71065 & 0.000007 & -4.4 & 26.3 & -6.8 \\
\hline V2873 & 890 & A & 1 & Male & 9 & 11 & 16 & 0.710534 & 0.000009 & -4.5 & 26.3 & -6.9 \\
\hline V2878 & 3 & E & 2 & Male & 25 & 34 & 34 & 0.710584 & 0.000011 & -4.7 & 26.1 & -7.1 \\
\hline V2893 & 898 & A & 1 & Female & 20 & 80 & 47 & 0.711261 & 0.000009 & -4.9 & 25.8 & -7.5 \\
\hline V2900 & 6 & E & 2 & Female & 30 & 36 & 35 & 0.709499 & 0.000009 & -5.6 & 25.2 & -8.6 \\
\hline V2904 & 901 & A & 1 & Female & 15 & 45 & 34 & 0.71042 & 0.000008 & -4.9 & 25.8 & -7.6 \\
\hline V2910 & 9 & E & 2 & Male & 10 & 13 & 36 & 0.710287 & 0.000009 & -5.6 & 25.2 & -8.6 \\
\hline V2916 & 12 & E & 2 & Male & 8 & 12 & 46 & 0.710339 & 0.000007 & -5 & 25.8 & -7.6 \\
\hline V2944 & 17 & E & 1 & Male & 34 & 43 & 46 & 0.710481 & 0.000008 & -5.1 & 25.7 & -7.8 \\
\hline V2948 & 18 & E & 2 & Male & 52 & 61 & $24 ?$ & 0.710617 & 0.00001 & -5.5 & 25.2 & -8.5 \\
\hline V2973 & 19 & E & 1 & Female & 40 & 46 & 36 & 0.708989 & 0.000007 & -5 & 25.7 & -7.7 \\
\hline V3038 & 180 & A & 1 & Female & 35 & 80 & 14 & 0.710016 & 0.00001 & -5.2 & 25.5 & -8 \\
\hline V3043 & 28 & E & 1 & Female & 40 & 60 & 35 & 0.710101 & 0.000008 & -4.9 & 25.8 & -7.6 \\
\hline V3087 & 1 & B & 2 & Male & 20 & 25 & 46 & 0.709898 & 0.000007 & -5 & 25.7 & -7.8 \\
\hline
\end{tabular}


Table 5 (continued)

\begin{tabular}{|c|c|c|c|c|c|c|c|c|c|c|c|c|}
\hline ID & Feature & Zone & Period & $\begin{array}{l}\text { Biological } \\
\text { sex }\end{array}$ & & $\begin{array}{l}\text { ath in } \\
1-\text { max) }\end{array}$ & $\begin{array}{l}\text { Dental } \\
\text { element }\end{array}$ & ${ }^{87} \mathrm{Sr} /{ }^{86} \mathrm{Sr}$ & $2 \mathrm{SE}$ & $\delta^{18} \mathrm{O}_{\mathrm{PDB}}$ & $\delta^{18} \mathrm{O}_{\text {SMOW }}$ & $\delta^{18} \mathrm{O}_{\mathrm{DW}}$ \\
\hline V3103 & 4 & B & 2 & Female & 20 & 34 & 37 & 0.709499 & 0.00001 & -5.6 & 25.1 & -8.7 \\
\hline V3104 & 5 & B & 2 & Female & 35 & 55 & 47 & 0.710455 & 0.00001 & -5.2 & 25.5 & -8 \\
\hline V3169 & 9 & B & 2 & Male & 20 & 40 & $16 ?$ & 0.71023 & 0.000006 & -4.9 & 25.9 & -7.5 \\
\hline V3201 & 16 & B & 2 & Male & 34 & 43 & 36 & 0.709905 & 0.000008 & -5.8 & 25 & -8.9 \\
\hline V3208 & 15 & B & 2 & Male & 18 & 34 & 46 & 0.710063 & 0.00001 & -5.7 & 25 & -8.8 \\
\hline V3221 & 22 & B & 2 & Male & 20 & 26 & 26 & 0.710228 & 0.00001 & -5.2 & 25.6 & -7.9 \\
\hline V3233 & 31 & B & 2 & Female & 22 & 40 & 26 & 0.710343 & 0.000009 & -4.8 & 26 & -7.4 \\
\hline V3234 & 30 & B & 2 & Male & 40 & 49 & 35 & 0.710149 & 0.000012 & -4.2 & 26.6 & -6.4 \\
\hline V3257 & 130 & $\mathrm{D}$ & 2 & Female & 20 & 34 & 35 & 0.711725 & 0.00001 & -5.8 & 25 & -8.9 \\
\hline V3278 & 3 & $\mathrm{D}$ & 2 & Female & 40 & 46 & $32 ?$ & 0.710561 & 0.00001 & -5 & 25.8 & -7.7 \\
\hline V3300 & 67 & B & 1 & Male & 31 & 80 & $26 ?$ & 0.710168 & 0.000007 & -4.6 & 26.2 & -7 \\
\hline V3306 & 69 & B & 0 & NTD & 15 & 80 & $16 ?$ & 0.711147 & 0.000009 & -4.6 & 26.2 & -7 \\
\hline V3327 & 81 & B & 0 & Male & 20 & 80 & 46 & 0.710451 & 0.000009 & -5.5 & 25.2 & -8.6 \\
\hline V3355 & 35 & B & 0 & NTD & 20 & 80 & $14 ?$ & 0.710323 & 0.000009 & -4.4 & 26.4 & -6.7 \\
\hline V3363 & 36 & B & 0 & NTD & 4 & 6 & 36 & 0.710134 & 0.000008 & -4.5 & 26.3 & -6.9 \\
\hline V3385 & 50 & B & 2 & Male & 38 & 61 & 43 & 0.710386 & 0.000011 & -5 & 25.8 & -7.7 \\
\hline V3386 & 57 & B & 1 & Female & 20 & 80 & 16 & 0.71032 & 0.000008 & -4.6 & 26.2 & -7 \\
\hline V3390 & 48 & B & 0 & Male & 23 & 33 & 26 & 0.709809 & 0.00001 & -5 & 25.8 & -7.7 \\
\hline V3398 & 55 & B & 0 & NTD & 20 & 80 & $16 ?$ & 0.710891 & 0.00001 & -5.7 & 25 & -8.8 \\
\hline V3426 & 92 & $\mathrm{D}$ & 2 & Male & 46 & 51 & 42 & 0.710046 & 0.000008 & -4.3 & 26.5 & -6.6 \\
\hline V3455 & 100 & $\mathrm{D}$ & 2 & Female & 25 & 34 & 35 & 0.710599 & 0.000009 & -4.9 & 25.9 & -7.4 \\
\hline V3483 & 106 & $\mathrm{D}$ & 2 & Male & 30 & 36 & 36 & 0.710622 & 0.000008 & -6.1 & 24.7 & -9.4 \\
\hline V3503 & 12 & $\mathrm{D}$ & 2 & Male & 20 & 30 & 46 & 0.710229 & 0.000008 & -5.1 & 25.7 & -7.8 \\
\hline V3511 & 16 & $\mathrm{D}$ & 2 & Female & 35 & 55 & $16 ?$ & 0.710638 & 0.000011 & -5.7 & 25 & -8.9 \\
\hline V3515 & 17 & $\mathrm{D}$ & 2 & Male & 12 & 16 & 36 & 0.70964 & 0.00001 & -4.4 & 26.3 & -6.8 \\
\hline V3524 & 19 & $\mathrm{D}$ & 2 & Male & 30 & 60 & 36 & 0.711797 & 0.000008 & -6.1 & 24.6 & -9.5 \\
\hline V3537 & 23 & $\mathrm{D}$ & 2 & Female & 30 & 36 & 46 & 0.711187 & 0.00001 & -5.6 & 25.2 & -8.6 \\
\hline V3538 & 24 & $\mathrm{D}$ & 2 & Female & 25 & 34 & $12 ?$ & 0.710511 & 0.00001 & -5.6 & 25.2 & -8.6 \\
\hline V3567 & 34 & $\mathrm{D}$ & 2 & Female & 34 & 43 & 34 & 0.710659 & 0.000011 & -4.2 & 26.6 & -6.3 \\
\hline V3607 & 99 & B & 0 & NTD & 20 & 30 & 75 & 0.709698 & 0.000009 & - & - & - \\
\hline V3620 & 56 & $\mathrm{D}$ & 2 & Male & 25 & 34 & 34 & 0.71004 & 0.000007 & -4.6 & 26.1 & -7.1 \\
\hline V3644 & 70 & $\mathrm{D}$ & 2 & Female & 40 & 49 & 15 & 0.710277 & 0.000012 & -5.2 & 25.5 & -8 \\
\hline V3696 & 60 & B & 1 & Female & 25 & 35 & 34 & 0.710193 & 0.000008 & -4 & 26.8 & -6 \\
\hline V3701 & 122 & $\mathrm{D}$ & 2 & Male & 16 & 80 & 43 & 0.710527 & 0.000007 & -5.3 & 25.4 & -8.2 \\
\hline V3702 & 123 & $\mathrm{D}$ & 2 & Male & 34 & 43 & 35 & 0.710495 & 0.000011 & -4.5 & 26.3 & -6.9 \\
\hline V3735 & 132 & $\mathrm{D}$ & 2 & Female & 35 & 55 & 44 & 0.710921 & 0.000008 & -5.7 & 25 & -8.8 \\
\hline V3797 & 2 & $\mathrm{C}$ & 2 & Female & 21 & 80 & 37 & 0.710053 & 0.000011 & -5 & 25.8 & -7.7 \\
\hline V3852 & 3 & $\mathrm{C}$ & 2 & Female & 32 & 50 & 43 & 0.709905 & 0.000008 & -5.5 & 25.2 & -8.5 \\
\hline V3857 & 191 & $\mathrm{D}$ & 2 & Male & 40 & 80 & 46 & 0.709845 & 0.000008 & -5.6 & 25.1 & -8.7 \\
\hline V3858 & 192 & $\mathrm{D}$ & 0 & Male & 20 & 80 & 26 & 0.710635 & 0.000008 & -4.6 & 26.2 & -7 \\
\hline V3866 & 196 & $\mathrm{D}$ & 2 & Male & 34 & 40 & 44 & 0.709705 & 0.000011 & -4.4 & 26.3 & -6.8 \\
\hline V3869 & 198 & $\mathrm{D}$ & 2 & Female & 34 & 40 & 35 & 0.710502 & 0.00001 & -4.9 & 25.9 & -7.4 \\
\hline V3941 & 165 & $\mathrm{D}$ & 0 & Male & 10 & 13 & 14 & 0.709894 & 0.000007 & - & - & - \\
\hline V3974 & 177 & $\mathrm{D}$ & 2 & Female & 37 & 43 & 46 & 0.709973 & 0.000007 & -5.1 & 25.7 & -7.8 \\
\hline V3975 & 174 & $\mathrm{D}$ & 2 & Male & 19 & 28 & 24 & 0.71107 & 0.000008 & -5.7 & 25.1 & -8.8 \\
\hline V3988 & 185 & $\mathrm{D}$ & 2 & Male & 40 & 80 & 44 & 0.710965 & 0.000009 & -5.6 & 25.2 & -8.6 \\
\hline V4033 & 234 & $\mathrm{D}$ & 2 & Male & 40 & 46 & 14 & 0.709992 & 0.000008 & -6.2 & 24.5 & -9.7 \\
\hline V4037 & 235 & $\mathrm{D}$ & 0 & Female & 41 & 47 & 46 & 0.708727 & 0.000008 & -4.7 & 26.1 & -7.1 \\
\hline
\end{tabular}


Table 5 (continued)

\begin{tabular}{|c|c|c|c|c|c|c|c|c|c|c|c|c|}
\hline \multirow{2}{*}{$\begin{array}{l}\text { ID } \\
\text { V4050 }\end{array}$} & \multirow{2}{*}{$\begin{array}{l}\text { Feature } \\
237\end{array}$} & \multirow{2}{*}{$\begin{array}{l}\text { Zone } \\
\mathrm{D}\end{array}$} & \multirow{2}{*}{$\begin{array}{l}\text { Period } \\
0\end{array}$} & \multirow{2}{*}{$\begin{array}{l}\begin{array}{l}\text { Biological } \\
\text { sex }\end{array} \\
\text { Male }\end{array}$} & \multicolumn{2}{|c|}{$\begin{array}{l}\text { Age at death in } \\
\text { years (min-max) }\end{array}$} & \multirow{2}{*}{$\begin{array}{l}\begin{array}{l}\text { Dental } \\
\text { element }\end{array} \\
35\end{array}$} & \multirow{2}{*}{$\begin{array}{c}{ }^{87} \mathrm{Sr} /{ }^{86} \mathrm{Sr} \\
0.710861\end{array}$} & \multirow{2}{*}{$\begin{array}{l}2 \mathrm{SE} \\
0.000009\end{array}$} & \multirow{2}{*}{$\frac{\delta^{18} \mathrm{O}_{\mathrm{PDB}}}{-4.8}$} & \multirow{2}{*}{$\frac{\delta^{18} \mathrm{O}_{\text {SMOW }}}{26}$} & \multirow{2}{*}{$\frac{\delta^{18} \mathrm{O}_{\mathrm{DW}}}{-7.3}$} \\
\hline & & & & & 37 & 46 & & & & & & \\
\hline V4073 & 248 & $\mathrm{D}$ & 0 & Male & 12 & 15 & 36 & 0.711334 & 0.000011 & -4.8 & 26 & -7.3 \\
\hline V4092 & 279 & $\mathrm{D}$ & 1 & Female & 7 & 11 & 16 & 0.709692 & 0.00001 & -5.2 & 25.6 & -8 \\
\hline V4093 & 280 & $\mathrm{D}$ & 1 & Female & 6 & 10 & 36 & 0.709715 & 0.000009 & -4.8 & 26 & -7.4 \\
\hline V4094 & 281 & $\mathrm{D}$ & 1 & Female & 33 & 46 & 36 & 0.710695 & 0.000007 & -5.3 & 25.4 & -8.2 \\
\hline V4095 & 282 & $\mathrm{D}$ & 1 & Male & 6 & 10 & 46 & 0.709921 & 0.000007 & -5 & 25.7 & -7.7 \\
\hline V4096 & 283 & $\mathrm{D}$ & 1 & Female & 3.5 & 6.5 & 83 & 0.709972 & 0.00001 & - & - & - \\
\hline V4149 & 258 & $\mathrm{D}$ & 1 & Female & 34 & 43 & 36 & 0.710015 & 0.00001 & -6 & 24.7 & -9.3 \\
\hline V4167 & 272 & $\mathrm{D}$ & 1 & Female & 30 & 36 & 27 & 0.710674 & 0.000009 & -4.9 & 25.8 & -7.6 \\
\hline V4233 & 3 & $\mathrm{D}$ & 2 & Female & 6 & 10 & $16 ?$ & 0.710754 & 0.000005 & -5.8 & 25 & -8.9 \\
\hline V4301 & 327 & $\mathrm{D}$ & 0 & Male & 15 & 18 & 36 & 0.71029 & 0.000008 & - & - & - \\
\hline V4322 & 330 & $\mathrm{D}$ & 0 & Female & 46 & 52 & 34 & 0.710992 & 0.000008 & -4.7 & 26.1 & -7.2 \\
\hline V4323 & 331 & $\mathrm{D}$ & 0 & Female & 43.3 & 49.3 & 33 & 0.710195 & 0.000007 & -4.9 & 25.9 & -7.5 \\
\hline V4361 & 349 & $\mathrm{D}$ & 0 & Female & 20 & 26 & 36 & 0.710413 & 0.000011 & -5.4 & 25.4 & -8.3 \\
\hline V4608 & 376 & $\mathrm{D}$ & 2 & Male & 40 & 46 & 34 & 0.711171 & 0.000011 & -4.4 & 26.3 & -6.8 \\
\hline V4801 & 509 & $\mathrm{D}$ & 1 & Female & 16 & 19 & 46 & 0.710147 & 0.000008 & -5.3 & 25.4 & -8.2 \\
\hline V4808 & 518 & $\mathrm{D}$ & 2 & Female & 19 & 28 & 46 & 0.7104 & 0.000008 & -4.6 & 26.2 & -7 \\
\hline V4831 & 521 & $\mathrm{D}$ & 1 & Female & 6 & 10 & 36 & 0.710394 & 0.000008 & -4.9 & 25.8 & -7.6 \\
\hline V4857 & 538 & $\mathrm{D}$ & 0 & Male & 28 & 37 & 36 & 0.710139 & 0.000007 & -5.4 & 25.3 & -8.4 \\
\hline V4928 & 541 & $\mathrm{D}$ & 0 & Male & 30 & 40 & 46 & 0.710147 & 0.000009 & -4.9 & 25.9 & -7.5 \\
\hline V4940 & 550 & $\mathrm{D}$ & 0 & Female & 13 & 19 & 36 & 0.710324 & 0.00001 & -5.4 & 25.4 & -8.3 \\
\hline V5053 & 5 & $\mathrm{E}$ & 1 & Male & 5 & 7 & 46 & 0.710428 & 0.000011 & -5.4 & 25.3 & -8.3 \\
\hline
\end{tabular}

Period: 0, no period assigned; 1 , AD 600-1500; 2, AD 1500-1829. Biological sex: NTD not determined. Dental element: notation conforms to Fédération Dentaire Internationale (FDI: syntax: <quadrant code $><$ tooth code $>$ )

Open Access This article is distributed under the terms of the Creative Commons Attribution 4.0 International License (http:// creativecommons.org/licenses/by/4.0/), which permits unrestricted use, distribution, and reproduction in any medium, provided you give appropriate credit to the original author(s) and the source, provide a link to the Creative Commons license, and indicate if changes were made.

\section{References}

Altena E, Kootker LM, Panhuysen RGAM (2016) Populatieonderzoek. In: Williams GL (ed) Memento Mori, Een archeologische opgraving rondom de St. Plechelmuskerk, Oldenzaal. vol ADC Monografie 21. ADC Monografie 21, ADC Archeoprojecten, Amersfoort, 211-302

Bataille CP, Laffoon J, Bowen GJ (2012) Mapping multiple source effects on the strontium isotopic signatures of ecosystems from the circumCaribbean region. Ecosphere 3(12):art118. https://doi.org/10.1890/ es12-00155.1

Van Beek R (2009) Reliëf in tijd en ruimte, Interdisciplinair onderzoek naar bewoning en landschap van Oost-Nederland tussen vroege prehistorie en middeleeuwen. University of Wageningen, PhD dissertation

Bentley RA (2006) Strontium isotopes from the Earth to the archaeological skeleton: A review. J Archaeol Method Theory 13:135-187

Beerbühl Schhulte M (2013) Networks of the Hanseatic League. European History Online (EGO) published by the Leibniz Institute of European History (IEG), Mainz. URL: http://www.ieg-ego.eu/ schultebeerbuehlm-2011-en

Bove B, Gauvard C (2014) Le Paris du Moyen Age. Belin, Paris

Bowen GJ (2010) Isoscapes: spatial pattern in isotopic biogeochemistry. Ann Rev Earth and Planet Sci 38:161-187. https://doi.org/10.1146/ annurev-earth-040809-152429

Brand H (2007) Baltic connections. Changing patterns in seaborne trade, c. 1450-1800. In: Bes L, Frankot E, Brand H (eds) Baltic connections. Archival guide to the maritime relations of the countries around the Baltic Sea (including the Netherlands) 14501800. vol I. Brill, Leiden, pp 1-24

Broadberry S, Campbell BMS, van Leeuwen B (2010) English medieval population: reconciling time series and cross sectional evidence. Available at https://www2.warwick.ac.uk/fac/soc/economics/staff/ sbroadberry/wp/medievalpopulation7.pdf

Cassidy LM, Martiniano R, Murphy EM, Teasdale MD, Mallory J, Hartwell B, Bradley DG (2016) Neolithic and Bronze Age migration to Ireland and establishment of the insular Atlantic genome. Proc Natl Acad Sci 113(2):368-373. https://doi.org/10.1073/pnas. 1518445113

Chenery C, Pashley V, Lamb A, Sloane HJ, Evans AS (2012) The oxygen isotope relationship between the phosphate and structural carbonate fractions of human bioapatite. Rapid Commun Mass Spectrom 26(3):309-319. https://doi.org/10.1002/rcm.5331

Coplen TB (1988) Normalization of oxygen and hydrogen isotope data. Chemi Geol: Isotope Geosci section 72:293-297

Darling WC, Bath AH, Talbot JC (2003) The O \& H stable isotopic composition of fresh waters in the British Isles: 2, surface waters 
and groundwater. Hydrol Earth Syst Sci 7(2):183-195. https://oi. org/10.5194/hess-7-183-2003

Daux V, Lécuyer C, Héran MA, Amiot R, Simon L, Fourel F, Martineau F, Lynnerup N, Reychler H, Escarguel G (2008) Oxygen isotope fractionation between human phosphate and water revisited. J Hum Evol 55(6):1138-1147. https://doi.org/10.1016/j.jhevol.2008.06.006

De Rooi C-J (2008) Waar de venen groeiden: de Achterhoek. HistorischGeografisch Tijdschrift 26:117-129

Dollinger P (1998) Die Hanse. Kröner, Stuttgart

Erickson J (1985) Strontium isotope characterization in the study of prehistoric human ecology. J Hum Evol 14(5):503-514. https://doi.org/ 10.1016/S0047-2484(85)80029-4

Evans JA, Montgomery J, Wildman G (2009) Isotope domain mapping of ${ }^{87} \mathrm{Sr} /{ }^{86} \mathrm{Sr}$ biosphere variation on the Isle of Skye, Scotland. J Geol Soc 166(4):617-631. https://doi.org/10.1144/0016-76492008-043

Evans JA, Montgomery J, Wildman G, Boulton N (2010) Spatial variations in biosphere ${ }^{87} \mathrm{Sr} /{ }^{86} \mathrm{Sr}$ in Britain. J Geol Soc 167(1):1-4. https://doi.org/10.1144/0016-76492009-090

Fockema Andreae SJ (1957) Hessenwegen. Mededelingen der Koninklijke Nederlandse Akademie der Wetenschappen, afdeling Letterkunde, Nieuwe reeks 20(11):283-301

Font L, van der Peijl G, van Leuwen C, van Wetten I, Davies GR (2015) Identification of the geographical place of origin of an unidentified individual by multi-isotope analysis. Sci Justice 55(1):34-42. https://doi.org/10.1016/j.scijus.2014.06.011

Frei KM, Frei R (2011) The geographic distribution of strontium isotopes in Danish surface waters: a base for provenance studies in archaeology, hydrology and agriculture. Appl Geochem 26(3):326-340. https://doi.org/10.1016/j.apgeochem.2010.12.006

Gerding MAW (1995) Vier eeuwen turfwinning. De verveningen in Groningen, Friesland, Drenthe en Overijssel tussen 1550-1950. $\mathrm{PhD}$ thesis Lanndbouwuniversiteit Wageningen, Wageningen

Goorhuis G (2009) Rovenius teksten en bronnen. Www. plechelmusbasiliek.nl

Groenewoudt BJ, van Haaster H, van Beek R, Brinkkemper O (2007) Towards a reverse image. Botanical research into the landscape history of the eastern Netherlands (1100 B.C.-A.D. 1500). Landscape History 29(1):17-33. https://doi.org/10.1080/01433768.2007. 10594587

Haak W, Brandt G, Jong HN, Meyer C, Ganslmeier R, Heyd V, Hawkesworth C, Pike AWG, Meller H, Alt KW (2008) Ancient DNA, strontium isotopes, and osteological analyses shed light on social and kinship organization of the Later Stone Age. Proc Natl Acad Sci 105(47):18226-18231. https://doi.org/10.1073/pnas. 0807592105

Haartsen A, Storms E (2009) Ontgonnen verleden. Regiobeschrijvingen provincie Overijssel. Directie Kennis, Rapport DK nr. 2009/dk116D, Ede

Hamre SS, Daux V (2016) Stable oxygen isotope evidence for mobility in medieval and post-medieval Trondheim, Norway. J Archaeol Sci Rep 8:416-425. https://doi.org/10.1016/j.jasrep.2016.06.046

Harris EC (1975) The stratigraphic sequence: a question of time. World Archaeol 7(1):109-121. https://doi.org/10.1080/00438243.1975. 9979624

Heidinga HA (1987a) Medieval settlement and economy north of the lower Rhine archaeology and history of Kootwijk and the Veluwe (the Netherlands). Cingula, Assen, p 9

Heidinga HA (1987b) Zwischen Friesen. Franken und Sachsen Einige Bemerkungen zur Gruppenbildung im frühen Mittelalter in den Niederlanden Studien zur Sachsenforschung 6:55-71

Hilgers A (2007) The chronology of late glacial and Holocene dune development in the northern central European lowland reconstructed by optically stimulated luminescence (OSL) dating. $\mathrm{PhD}$ thesis, University of Cologne

Hoppa RD (1996) Representativeness and bias in cemetery samples: implications for palaeodemographic reconstructions of past populations. PhD dissertation, Department of Anthropology, McMaster University

Hoppa RD (2001) The once and future palaeodemography. In: Sawchuk L, Pfeiffer S (eds) Out of the Past: The History of Human Osteology at the University of Toronto. CITDPress, University of Toronto at Scarborough, pp -. Available at https://tspace.library.utoronto.ca/ citd/Osteology/Hoppa.html

Horsten FH (2005) Doorgaande wegen in Nederland, $16^{\mathrm{e}}$ tot $19^{\mathrm{e}}$ eeuw. Een historische wegenatlas, Aksan, Amsterdam

IAEA/WMO (2016) Global network of isotopes in precipitation. The GNIP Database. Accessible at: http://www.iaea.org/water.

Jackes M (2011) Representativeness and bias in archaeological skeletal samples. In: Agerwal C, Glencross BA (eds) Social bioarchaeology. Wiley-Blackwell, pp 107-146. https://doi.org/10.1002/ 9781444390537.ch5

Kennedy CD, Bowen GJ, Ehleringer JR (2011) Temporal variation of oxygen isotope ratios $\left(\delta^{18} \mathrm{O}\right)$ in drinking water: implications for specifying location of origin with human scalp hair. Forensic Sci Int 208(1-3):156-166. https://doi.org/10.1016/j. forsciint.2010.11.021

Kootker LM (2014) Strontiumisotopenonderzoek naar mobiliteit. In: Lauwerier RCGM, De Kort JW (eds) Merovingers in een villa 2. Romeinse villa en Merovingisch grafveld Borgharen - Pasestraat. Onderzoek 2012. Rapportage Archeologische Monumentenzorg 222, Amersfoort, pp 109-112

Kootker LM, Mbeki L, Morris AG, Kars H, Davies GR (2016a) Dynamics of Indian Ocean slavery revealed through isotopic data from the Colonial era Cobern Street burial site, Cape Town, South Africa (1750-1827). PLoS One 11(6):e0157750. https://doi.org/10. 1371/journal.pone. 0157750

Kootker LM, Van Lanen RJ, Kars H, Davies GR (2016b) Strontium isoscapes in the Netherlands. Spatial variations in ${ }^{87} \mathrm{Sr} /{ }^{86} \mathrm{Sr}$ as a proxy for palaeomobility. J Archaeol Sci Rep 6:1-13. https://doi. org/10.1016/j.jasrep.2016.01.015

Kootker LM, Geerdink C, Van den Broeke PW, Davies GR, Kars H (2017) Breaking traditions: an isotopic study on the changing funerary practices in the Dutch Iron Age (800 - 12 BC). Archaeometry. https://doi.org/10.1111/arcm.12333.

Koster EA (2009) The European aeolian sand belt: geoconservation of drift sand landscapes. Geoheritage 1(2-4):93-110. https://doi.org/ 10.1007/s12371-009-0007-8

Krueger HW (1985) Sr isotopes and $\mathrm{Sr} / \mathrm{Ca}$ in bone. Paper presented at the Biomineralization Conference. Airlie House, Warrenton, VA April $14-17$

Laffoon JE, Sonnemann TF, Shafie T, Hofman CL, Brandes U, Davies GR (2017) Investigating human geographic origins using dualisotope $\left({ }^{87} \mathrm{Sr} /{ }^{86} \mathrm{Sr}, \delta^{18} \mathrm{O}\right)$ assignment approaches. PLoS One 12(2): e0172562. https://doi.org/10.1371/journal.pone.0172562

Lecolle P (1985) The oxygen isotope composition of landsnail shells as a climatic indicator - applications to hydrogeology and paleoclimatology. Chem Geol 58(1-2):157-181. https://doi.org/10.1016/01689622(85)90036-3

Lightfoot E, O'Connell TC (2016) On the use of biomineral oxygen isotope data to identify human migrants in the archaeological record: intra-sample variation, statistical methods and geographical considerations. PLoS One 11(4):e0153850. https://doi.org/10.1371/ journal.pone. 0153850

Ligtenbarg A, Spit N (2010) Hanze, tol \& handelswegen in OostNederland. Vereniging Het Museum, Winterswijk

Lourens P, Lucassen J (1997) Inwoneraantallen van Nederlandse steden ca. NEHA, Amsterdam, pp 1300-1800

Maat GJR, Panhuysen RGAM, Mastwijk RW (2002) Manual for the physical anthropology report. Leiden

McPherson PM (2005) Tracing change: an isotopic investigation of Anglo-Saxon childhood diet. PhD thesis, University of Sheffield 
Mann HB, Whitney DR (1947) On a test of whether one of two random variables is stochastically larger than the other. Ann Math Stat 18(1): 50-60. https://doi.org/10.1214/aoms/1177730491

Maresh MM (1955) Linear growth of long bones of extremities from infancy through adolescence. Am J Dis Children 89:125-142

McManus E, Montgomery J, Evans J, Lamb A, Brettell R, Jelsma J (2013) "To the land or to the sea": diet and mobility in early medieval Frisia. J Island Coastal Archaeol 8(2):255-277. https://doi.org/ 10.1080/15564894.2013.787565

Moorrees CF, Fanning EA, Hunt EE (1963) Age variation of formation stages for 10 permanent teeth. J Dent Res 42(6):490-502. https:// doi.org/10.1177/00220345630420062701

Morozova I, Flegontov P, Mikheyev AS, Bruskin S, Asgharian H, Ponomarenko P, Klyuchnikov V, ArunKumar GP, Prokhortchouk E, Gankin Y, Rogaev E, Nikolsky Y, Baranova A, Elhaik E, Tatarinova TV (2016) Toward high-resolution population genomics using archaeological samples. DNA Res 23(4):295-310. https://doi. org/10.1093/dnares/dsw029

Naumann E, Krzewińska M, Götherström A, Eriksson G (2014) Slaves as burial gifts in Viking Age Norway? Evidence from stable isotope and ancient DNA analyses. J Archaeol Sci 41:533-540. https://doi. org/10.1016/j.jas.2013.08.022

Nelson SJ, Ash MM (2010) Wheeler's dental anatomy, physiology, and occlusion, 9th edn. Saunders Elsevier, St. Louis, Missouri

Ostkamp S (1999) De opgraving van het St. Agnesklooster in Oldenzaal, Amersfoort

Oude Nijhuis J (2007) Oldenzaal van hof naar stad. Overijsselse Historische Bijdragen Verslagen en mededelingen van de Vereeniging tot beoefening van Overijsselsch Regt en Geschiedenis 12:109-121

Pellegrini M, Snoeck C (2016) Comparing bioapatite carbonate pretreatments for isotopic measurements: part 2-impact on carbon and oxygen isotope compositions. Chem Geol 420:88-96. https:// doi.org/10.1016/j.chemgeo.2015.10.038

Pellegrini M, Pouncett J, Jay M, Pearson MP, Richards MP (2016) Tooth enamel oxygen "isoscapes" show a high degree of human mobility in prehistoric Britain. Sci Rep 6(1):34986. https://doi.org/10.1038/ srep34986

Pirenne H (2014) (1925) Medieval cities: their origins and the revival of trade, Updated edn. Princeton University Press, Princeton Classics. https://doi.org/10.1515/9781400851201

Pollard AM, Pellegrini M, Lee-Thorp JA (2011) Technical note: some observations on the conversion of dental enamel $\delta^{18} \mathrm{O}_{\mathrm{p}}$ values to $\delta^{18} \mathrm{O}_{\mathrm{w}}$ to determine human mobility. Am J Phys Anthropol 145(3): 499-504. https://doi.org/10.1002/ajpa.21524

Prowse TL, Barta JL, von Hunnius TE, Small AM (2010) Stable isotope and ancient DNA evidence for geographic origins at the site of Vagnari (2nd-4th centuries AD), Italy. In: Eckhart H (ed) Roman diasporas: archaeological approaches to mobility and diversity in the roman empire. R.I.: journal of roman archaeology, supplement 78, Portsmouth, pp 175-198

Rutte R, van Engen H (2007) Met dank aan de landsheer. Enkele hoofdlijnen in de ontstaansgeschiedenis van de Overijsselse steden Overijsselse Historische Bijdragen Verslagen en mededelingen van de Vereeniging tot beoefening van Overijsselsch Regt en Geschiedenis 12:177-204

Santos FR, Pandya A, Tyler-Smith C (1998) Reliability of DNA-based sex tests. Nat Genet 18(2):103. https://doi.org/10.1038/ng0298-103

Schaefer M, Black S, Scheuer L (2009) Juvenile osteology: a laboratory and field manual. Elsevier Academic Press, Burlington

Seyger GA (2005) Hanzerijkdom. Armen- en ziekenzorg in Twente (7971626). Cartularium Oldenzaals OLV-gilde: $63-82$

Snoeck C, Pellegrini M (2015) Bioapatite carbonate pre-treatments for isotopic measurements: part 1 -impact on structure and chemical composition. Chem Geol 417:394-403. https://doi.org/10.1016/j. chemgeo.2015.10.004.

Steinlechner M, Berger B, Niederstätter H, Parson W (2002) Rare failures in the amelogenin sex test. Int J Legal Med 116(2):117-120. https:// doi.org/10.1007/s00414-001-0264-9

Tolksdorf JF, Kaiser K (2012) Holocene aeolian dynamics in the European sand-belt as indicated by geochronological data. Boreas 41(3):408-442. https://doi.org/10.1111/j.1502-3885.2012.00247.x

Ubelaker D (1989) Human skeletal remains: excavation, analysis, interpretation. Aldine Publishing, Chicago

Van Beek R, Gouw-Bouman MTIJ, Bos JAA (2015a) Mapping regional vegetation developments in Twente (the Netherlands) since the late glacial and evaluating contemporary settlement patterns. Neth J Geosci 94:229-255

Van Beek R, Maas GJ, van den Berg E (2015b) Home turf: an interdisciplinary exploration of the long-term development, use and reclamation of raised bogs in the Netherlands. Landscape. History 36(2): $5-34$

Van Genabeek, RJM (2003) Oldenzaal-Schoolstraat. BAAC rapport 01.106, 's-Hertogenbosch

Van Lanen RJ, Pierik HJ (2017) Calculating connectivity patterns in delta landscapes: modelling Roman and early-medieval route networks and their stability in dynamic lowlands. Quat Int. https://doi.org/ 10.1016/j.quaint.2017.03.009

Van Lanen RJ, Kosian MC, Groenewoudt BJ, Jansma E (2015a) Finding a way: modelling landscape prerequisites for Roman and earlymedieval routes in the Netherlands. Geoarchaeol: An Int J 30(3): 200-222. https://doi.org/10.1002/gea.21510

Van Lanen RJ, Kosian MC, Groenewoudt BJ, Spek T, Jansma E (2015b) Best travel options: modelling Roman and early-medieval routes in the Netherlands using a multi-proxy approach. J Archaeol Sci: Rep 3:144-159. https://doi.org/10.1016/j.jasrep.2015.05.024

Van Lanen RJ, Groenewoudt BJ, Spek T, Jansma E (2016) Route persistence. Modelling and quantifying historical route-network stability during the last two millennia: a case study from the Netherlands. Archaeological and Anthropological Sciences:doi:https://doi.org/ 10.1007/s12520-12016-10431-Z

Van Vliet K (2002) In kringen van kanunniken. Munsters en kapittels in het bisdom Utrecht. Walburg Pers, Zutphen, pp 695-1127

Waldron T (1994) Counting the dead: the epidemiology of skeletal populations. John Wiley \& Sons, Chichester

Weustink HJM (1962) De rechtsgeschiedenis van de stad Oldenzaal en van de mark Berghuizen tot 1795. Van Gorcum, Assen

Williams GL (2016) Memento Mori. Een archeologische opgraving rondom de St. Plechelmuskerk, Oldenzaal Oldenzaal. ADC Monografie 21. ADC ArcheoProjecten, Amersfoort

Willmes M, McMorrow L, Kinsley L, Armstrong R, Aubert M, Eggins S, Falguères C, Maureille B, Moffat I, Grün R (2014) The IRHUM (Isotopic Reconstruction of Human Migration) database - bioavailable strontium isotope ratios for geochemical fingerprinting in France. Earth Syst Sci Data 6(1):117-122. https://doi.org/10.5194/ essd-6-117-2014

Workshop of European Anthropologists (1980) Recommendations for age and sex diagnoses of the skeleton. J Hum Evol 9:517-549

Wright LE (2005) Identifying immigrants to Tikal, Guatemala: defining local variability in strontium isotope ratios of human tooth enamel. J Archaeol Sci 32(4):555-566. https://doi.org/10.1016/j.jas.2004.11.011

Wright LE, Schwarcz HP (1998) Stable carbon and oxygen isotopes in human tooth enamel: identifying breastfeeding and weaning in prehistory. Am J Phys Anthropol 106(1):1-18. https://doi.org/10.1002/ (SICI)1096-8644(199805)106:1<1::AID-AJPA1>3.0.CO;2-W 